\title{
Influence of Grass-Based Diets on Milk Fatty Acid Composition and Milk Lipolytic System in Tarentaise and Montbéliarde Cow Breeds
}

\author{
A. Ferlay, ${ }^{\star 1}$ B. Martin, ${ }^{\star}$ Ph. Pradel, $†$ J. B. Coulon, ${ }^{\star}$ and Y. Chilliard ${ }^{\star}$ \\ *Unité de Recherches sur les Herbivores, INRA-Theix, France \\ †Domaine de la Borie, INRA Marcenat, France
}

\begin{abstract}
Two experiments were conducted to evaluate the effects of nature of forage on fatty acid composition and lipolytic system in cow milk to increase the nutritional quality of dairy products. Each experiment was divided into a 4-wk preexperimental and 6- or 8-wk experimental period. During the 2 preexperimental periods, 56 midlactating Montbéliarde or Tarentaise cows received a diet based on corn silage. Subsequently, in Experiment 1, 40 cows were allocated into 5 groups ( 4 Montbéliarde and 4 Tarentaise cows per group) and assigned to dietary treatments: corn silage (87\% of dry matter intake), grass silage (86\%), ryegrass hay (90\%), mountain natural grassland hay (87\%), or a diet rich in concentrate (CONC, 65/35\% concentrate/hay). In Experiment 2,16 cows divided into 2 groups were fed during 3 or $6 \mathrm{wk}$ mountain natural pasture (100\%) or mountain natural grassland hay (87\%). Principal component analysis was applied to describe the relationships among dairy performances, milk fatty acids (FA), and lipolytic system. The milk 18:0, cis-9-18:1, trans-1118:1, and cis-9, trans-11-18:2 percentages were closely associated with 3 -wk mountain natural pasture diet, whereas short- and medium-chain (mostly saturated) FA were associated with the CONC diet. Tarentaise milk fat contained a lower proportion ( -3 to $4 \mathrm{~g} / 100 \mathrm{~g}$ ) of 16:0 and higher proportions of stearic acid and fewer markedly polyunsaturated FA than Montbéliarde milk fat. Milk lipolysis was lowest for CONC and corn silage groups. Milk from Tarentaise cows presented lower initial free FA and postmilking lipolysis. Diets given to cows, especially young grass, modified the milk content of FA with a putative nutritional effect on human health.
\end{abstract}

Key words: forage, milk fatty acid, conjugated linoleic acid, milk lipolytic system

Received May 9, 2005.

Accepted April 21, 2006

${ }^{1}$ Corresponding author: ferlay@clermont.inra.fr

\section{INTRODUCTION}

Conjugated linoleic acids (CLA) and their main isomer, rumenic acid (RA), in milk of ruminants have been shown to have potent anticarcinogenic effects in rats and mice (Parodi, 1999). Because of the potential health benefits that could arise from CLA consumption, a considerable research effort is being made to increase its content in dairy products. The CLA content of milk and dairy products depends on ruminal production of CLA and trans-11-18:1 (vaccenic acid) and on the activity of stearoyl-coenzyme A desaturase (SCD) in mammary tissue. Indeed, vaccenic acid formed in the rumen can be desaturated by SCD to form RA (up to 65 to $97 \%$ of total RA content; Griinari et al., 2000; Kay et al., 2004; Loor et al., 2005b). Among factors liable to modify milk RA content, nutritional factors have a major influence (Chilliard et al., 2000; Bauman and Griinari, 2003). The nature of forage could modify the milk fatty acid (FA) composition. Indirect comparisons between studies show that milk fat from corn silage diets is richer in short-chain FA and linoleic acid and poorer in $\alpha$ linolenic acid and RA when compared with grass silage or pasture diets (Chilliard et al., 2001). Compared with fresh grass, grass silage disadvantages mono- and polyunsaturated FA, including CLA. The breed could also influence the milk FA profiles (Palmquist et al., 1993). However, few data are available on the interaction between breed and nutritional factors.

Nutritional factors could also affect the milk lipolytic system and hence modify the sensorial quality of milk and dairy products. Milk fat lipolysis is the hydrolysis of fat globule triglycerides into FFA. The development of rancid flavor in cold stored milk is due to FFA, especially to free butyric acid and short-chain FA (Chilliard et al., 2003). Spontaneous lipolysis in cold stored milk is due to the action of milk lipoprotein lipase (LPL) and varies according to different genetic, physiological, or nutritional factors. However, few studies indicated the effect of nature of forage on milk lipolysis and LPL activity. It has been shown that breed has a major influence on the milk lipolytic system in dairy goats (Chilliard et al., 2003), but this factor received little attention in dairy cows (Chazal and Chilliard, 1987). 
The objectives of these experiments were to determine the effects of the nature of forage and cow breed on milk FA composition and lipolytic system.

\section{MATERIALS AND METHODS}

\section{Animals and Diets}

Two experiments were performed from February to June 2000, using a protocol approved by the Animal Care Committee of INRA. All experimental procedures were conducted according to the French recommendations for the use of experimental animals including animal welfare and appropriate conditions (Guidelines, 18 April 1988, cited by Veissier, 1999).

\section{Experiment 1}

Forty lactating cows were divided into 5 groups of 8 cows based on similarity in calving date, milk yield, fat content, protein content, DIM, and parity (7 primiparous Tarentaise and 8 primiparous Montbéliarde cows, respectively). Each treatment group included both 4 Montbéliarde and 4 Tarentaise cows, and 5 multiparous and 3 primiparous cows. The mean DIM was 83 (SD = 16) at the first day of sampling. Average BW of the animals at the start of the experiment was 597 and $545 \mathrm{~kg}(\mathrm{SD}=53.5$ and $52.5 \mathrm{~kg})$ for Montbéliarde and Tarentaise breeds, respectively.

The experiment was divided into 3 -wk preexperimental (covariate period) and 6-wk experimental periods, respectively. The first week of experimental period was used for adjustment to diets, and wk 6 was for data collection. During the preexperiment, cows were adapted to a diet containing on average $11.5 \mathrm{~kg}$ of DM corn silage and $1.8 \mathrm{~kg}$ of concentrate. This concentrate comprised $61.3 \%$ barley, $22.1 \%$ soybean meal, and $16.6 \%$ urea. Then the cows were allocated into 5 groups to receive one of the diets for the entire experiment: concentrate diet (CONC, 65\% of DMI with $35 \%$ of cocksfoot hay), corn silage (CS, 87\% of DMI), ryegrass silage (RS, $86 \%$ of DMI), ryegrass hay (RH, 90\% of DMI), and mountain natural grassland hay (NGH, 87\% of DMI). Mountain natural grassland hay was prepared from a first cut on May 5, 1999, and barn-dried. Ryegrass silage was prepared from a first cut of perennial ryegrass on June 6,1999 , with the use of silage additive (formic acid, $3 \mathrm{~L} / \mathrm{t}$ ). The cocksfoot hay (first cycle) was harvested on July 2, 1999. The length of cut was 50 to $70 \mathrm{~mm}$. Ryegrass hay was harvested during late July 1999 (second cycle) and was barn-dried. The corn silage was prepared during September 1999 without the use of silage additive and using a precision-chop forage harvester. The mean length of cut was $200 \mathrm{~mm}$. The nutri- tive value of forages is presented in Table 1. Rolled barley and soybean meal were offered on top of forage in 2 equal meals daily, except for the CONC diet (4 times). The diets were calculated for each cow from BW and $4 \% \mathrm{FCM}$ yield at wk 2 and 3 of the preexperiment. The energy supply was calculated to be equivalent in the different groups and to cover 100 to $105 \%$ of energy requirements for maintenance and production. The diets were calculated so that protein intake covered at least $105 \%$ of the requirements for proteins digestible in the intestine (PDI, INRA, 1989). The quantities of forage and concentrate remained unchanged for any given animal throughout the experimental period to fulfill the previous objectives. The cows were housed in tie stalls, and had constant access to water and tracemineralized salt blocks. Preprandial BW was measured at the end of each period.

\section{Experiment 2}

Experiment 2 was a follow up to Experiment 1 with 3 -wk preexperimental (covariate period) and 8-wk experimental periods, respectively. Sixteen lactating cows were divided into 2 groups with 4 Montbéliarde and 4 Tarentaise cows, and 5 multiparous and 3 primiparous cows per group. The mean DIM was $103(\mathrm{SD}=18)$ at the first day of sampling. During the preexperiment, cows were adapted to the same diet as described in Experiment 1 . Then the animals were divided into 2 groups and, after a 2-wk transition period, were fed the same grassland hay as used in Experiment 1 (87\% of DMI, NGH3 or NGH6) or mountain natural pasture (98\% of DMI, PAS3 or PAS6 diets), and milk was sampled during wk 3 or 6 , respectively. The cows were on pasture and were brought twice daily into the barn to be fed a supplement of soybean meal $(0.5 \mathrm{~kg} / \mathrm{cow}$ per d) plus minerals and premix, and milked. From May 15 (turn-out to pasture) until June 4, 2000 (wk 1 to 3), cows grazed a pasture. From this date until June 26 (wk 6), cows grazed another pasture. Grazing cows were moved daily to a new paddock after the morning milking. An electrified nylon string was moved across the field once daily to allow the cows to graze an area that would supply adequate supplemental pasture. The pasture grazed consisted of 32 species with about 50\% graminae (Festuca rubra was the main constituent, estimated at $27 \%$ of crude weight).

\section{Sample Collection and Analyses}

Refusals, if any, were collected and weighed daily to calculate the net intake of each diet. Feed samples for chemical analyses were collected once every week during each collection period and pooled to provide one 
Table 1. Nutritive value and digestibility of forages (Experiments 1 and 2)

\begin{tabular}{|c|c|c|c|c|c|}
\hline Ingredient & $\begin{array}{l}\text { Cocksfoot } \\
\text { hay }\end{array}$ & $\begin{array}{l}\text { Corn } \\
\text { silage }\end{array}$ & $\begin{array}{l}\text { Ryegrass } \\
\text { silage }\end{array}$ & $\begin{array}{l}\text { Ryegrass } \\
\text { hay }\end{array}$ & $\begin{array}{l}\text { Mountain } \\
\text { natural } \\
\text { grassland } \\
\text { hay }\end{array}$ \\
\hline $\mathrm{OM}(\mathrm{g} / \mathrm{kg}$ of $\mathrm{DM})$ & 924 & 910 & 906 & 905 & 904 \\
\hline $\mathrm{CP}(\mathrm{g} / \mathrm{kg}$ of $\mathrm{DM})$ & 91 & 75 & 133 & 133 & 190 \\
\hline Crude fiber ( $\mathrm{g} / \mathrm{kg}$ of $\mathrm{DM})$ & 352 & 177 & 281 & 256 & 280 \\
\hline $\mathrm{OM}$ digestibility $^{1}(\%)$ & 60.0 & 72.8 & 74.6 & 73.0 & 73.4 \\
\hline Net energy $^{2}(\mathrm{MJ} / \mathrm{kg}$ of DM $)$ & 4.76 & 6.68 & 6.61 & 6.25 & 6.25 \\
\hline $\mathrm{PDIN}^{2,3}(\mathrm{~g} / \mathrm{kg}$ of $\mathrm{DM})$ & 57 & 45 & 80 & 83 & 118 \\
\hline $\mathrm{PDIE}^{2,4}(\mathrm{~g} / \mathrm{kg}$ of $\mathrm{DM})$ & 72 & 71 & 73 & 91 & 105 \\
\hline
\end{tabular}

${ }^{1}$ OM digestibility was measured on sheep (Coulon et al., 1994).

${ }^{2}$ Values were calculated according to equations from INRA (1989) and OM digestibility.

${ }^{3}$ PDIN $=$ Proteins digestible in the intestine, when the degraded $\mathrm{N}$ is not limiting.

${ }^{4} \mathrm{PDIE}=$ Proteins digestible in the intestine, when the energy is not limiting.

sample per period. Samples of fresh pasture were collected during wk 3 and 6 from the paddocks before grazing and stored at $-20^{\circ} \mathrm{C}$.

Dried samples of feed ingredients were ground through a mill using a 1-mm screen. Ground samples were analyzed for DM, crude fiber, CP, and mineral content. Chemical analyses were expressed on a DM $\left(105^{\circ} \mathrm{C}\right)$ basis. A digestibility study using sheep was designed to determine the digestibility of OM of the forages described in Table 1. For FA analysis, samples of forages were pooled by period and frozen at $-20^{\circ} \mathrm{C}$ until lyophilization (Thermovac TM-20, Froilabo, Ozoir-La-Ferrière, France) and grinding. Fat was extracted using a mixture of chloroform and methanol (2:1, vol/vol) according to Folch et al. (1957; Table 2).

Milk yield was recorded at each milking, and 4 milk samples per milking were collected from 2 consecutive milkings on $\mathrm{d} 2$ during the last week of each period. Milking times were at 0545 and $1545 \mathrm{~h}$. One set of samples was preserved in tubes with bronopol-B2 (Trillaud, Surgères, France) and stored at $4^{\circ} \mathrm{C}$ until analysis for fat, protein, and lactose, using an infrared spectrophotometer (CILAL, Theix, France) according to standard procedures (AOAC, 1997). Milk calcium and phosphorus contents were determined by atomic absorption spectrophotometry (Pearce, 1977) and spectrophotometry (AFNOR, 1992), respectively. Milk urea content was determined by dimethylamino-4-benzaldehyde colorimetric method (Potts, 1967). The second set of samples was stored at $-20^{\circ} \mathrm{C}$ until freeze-dried. Milk samples of morning and evening milkings were pooled in proportion to provide one representative sample for analysis of FA composition by GLC (Trace GC 2000 Series, ThermoFinnigan, Les Ulis, France) after preparation of methyl esters according to Glass (1971) and modified by Sébédio et al. (1999). Esters of FA were separated on a fused silica capillary column (CPSil 88, $100 \mathrm{~m} \times$ $0.25 \mathrm{~mm}$ id with $0.20-\mu \mathrm{m}$ film thickness; Chrompack,

Table 2. Fatty acid (FA) composition of feedstuffs

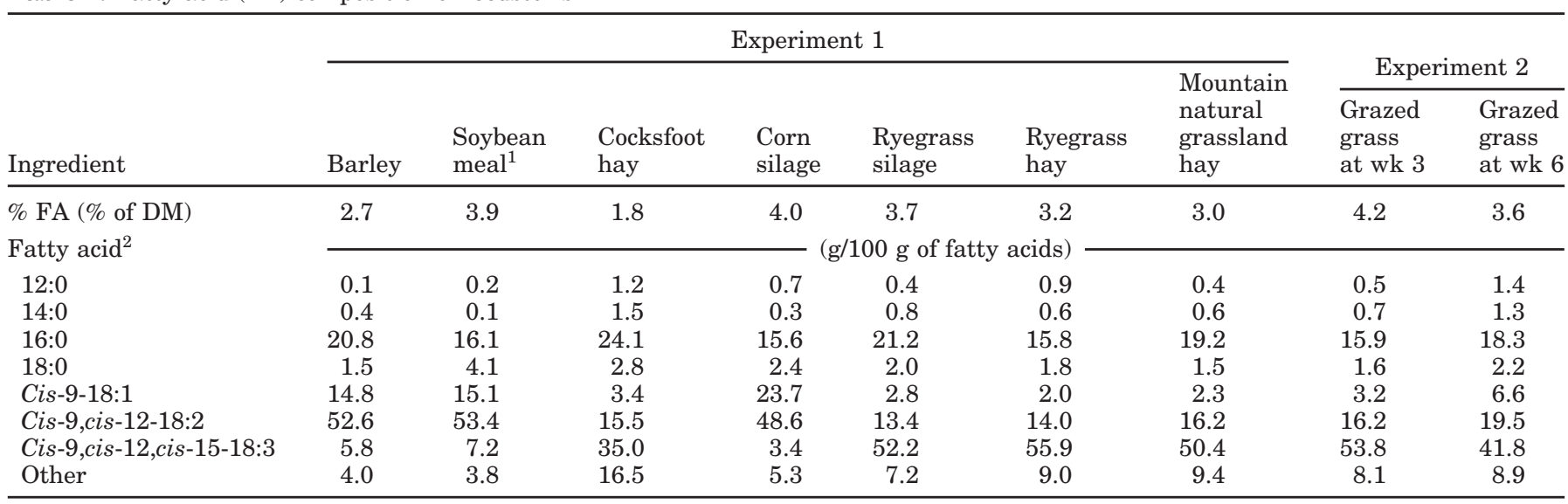

${ }^{1}$ Solvent-extracted soybean meal.

${ }^{2}$ Expressed as number of carbons:number of double bonds. Only FA having percentages higher than $1 \%$ in at least one feedstuff are mentioned. 
Middelburg, the Netherlands). Column temperature was held at $70^{\circ} \mathrm{C}$ for $4 \mathrm{~min}$ and then raised $13^{\circ} \mathrm{C} / \mathrm{min}$ to $175^{\circ} \mathrm{C}$, held for $27 \mathrm{~min}$, then increased by $4^{\circ} \mathrm{C} / \mathrm{min}$ to a final temperature of $215^{\circ} \mathrm{C}$, which was then held for $31 \mathrm{~min}$. Temperature of the injector and flame-ionization detector were maintained at 250 and $280^{\circ} \mathrm{C}$, respectively. Hydrogen was the carrier gas; constant linear flow rate was set at $1.2 \mathrm{~mL} / \mathrm{min}$. Individual FA methyl esters (FAME) were identified by comparison of gas chromatography peaks with peaks of known standard mixture of FAME (Supelco 37 Component FAME mix reference 47885 , Bellefonte, PA, and a butter reference standard, BCR 164, Commission of the European Communities, Community Bureau of Reference, Brussels, Belgium). The BCR 164 was used on each day of analysis to determine recoveries and correction factor for individual FAME from $\mathrm{C} 4$ to $\mathrm{C} 10$ because these FA are potentially volatile. Cis-9,trans-13-18:2 was identified by its retention time on gas chromatography (Ulberth and Henninger, 1994). Molecular weight of each FAME was used to obtain the percentage of each FA.

The third set of samples (at morning milking) was taken for determination of initial FFA content and FFA content after $24 \mathrm{~h}$ of cold storage. Immediately after milking, an 18-mL sample was taken, heated to $60^{\circ} \mathrm{C}$ for $30 \mathrm{~min}$ to destroy lipase activity, and stored $\left(+4^{\circ} \mathrm{C}\right)$ until tested for initial FFA content. A second 18-mL sample was stored at $4^{\circ} \mathrm{C}$ for $24 \mathrm{~h}$, then heated and stored at $4^{\circ} \mathrm{C}$ until tested for FFA content (FFA-24). A fourth set of samples (at morning milking) was frozen at $-20^{\circ} \mathrm{C}$ immediately after milking until analysis of milk LPL activity. The FFA content of milk was measured by the copper soap method (Jellema, 1991). The results are expressed in milliequivalents of FFA per $100 \mathrm{~g}$ of fat. Determination of milk LPL activity was measured using an artificial emulsion containing ${ }^{3} \mathrm{H}$ triolein emulsion (Faulconnier et al., 1994). Enzyme activity was expressed as nanomoles per minute per milliliter.

Blood samples were taken on d 2 of the last week of each experimental period, from each cow before the morning feeding from one coccygeal (tail) vessel, into tubes containing EDTA $(2.1 \mathrm{mg} / \mathrm{mL})$. Plasma was separated by centrifugation immediately after sampling at $3,000 \times g$ for $15 \mathrm{~min}$ at $20^{\circ} \mathrm{C}$. Plasma samples were frozen at $-20^{\circ} \mathrm{C}$ until analyzed for NEFA, glucose, urea, and BHBA using a multianalyzer (Elan, Merck-Clevenot, Nogent-sur-Marne, France) according to Ferlay and Chilliard (1999). Insulin was also determined by radioimmunoassay (Insik-1 M kit, Oris Industry, Gifsur-Yvette, France) with a sensitivity of $20 \mathrm{pmol} / \mathrm{L}$. The intra- and interassay CV were 9 and 13\%, respectively.

\section{Statistical Analyses}

Preexperiment. Breed effect was calculated using data obtained during the preexperimental period of the 2 experiments. Data were analyzed by the GLM procedure of SAS (2000), with breed, experiment, and breed $\times$ experiment interaction as main effects. Differences between breeds or experiments were performed by using the procedure of least square means (SAS Institute, 2000). Significance was declared at $P<0.05$.

Experiment 1. A covariate term was calculated as the deviation between each individual cow and mean of the cow's breed. This covariate term using the data obtained from the last week of preexperimental period was included in the model. Data were analyzed by the GLM procedure of SAS (2000), with covariate, diet, breed, and breed $\times$ diet as main effects. Differences between diets or breeds within diet were performed by using the procedure of least squares means (SAS, 2000). Significance was declared at $P<0.05$. Only significant interactions were noted in the tables. The covariate term was not used for the analysis of DM and nutrient intakes because the distributed amounts were calculated according to the experimental design and so were imposed.

Experiment 2. We used 2 statistical models. First, for grazing cows, DM and nutrient intakes were not measured but estimated and so these data were not statistically analyzed. Dry matter and nutrient intakes for NGH diet were analyzed with repeated measures using the MIXED procedure of SAS (SAS Institute, 2000). The statistical model included covariate, week, breed, week $\times$ breed interaction, and residual error. Second, all other data were analyzed with repeated measures using the MIXED procedure of SAS (SAS Institute, 2000), with covariate, week, diet, breed, diet $\times$ breed, week $\times$ diet, week $\times$ breed interactions, and residual error as fixed effects and cow as random effect. Differences between diets or breeds within diet were performed by using the procedure of least square means (SAS Institute, 2000). Only significant interactions are noted in the tables. Significance was declared at $P<$ 0.05 . The calculation of the covariate term was the same as described in Experiment 1.

For both the experiments, the desaturase index was calculated for 4 pairs of fatty acids that represent products and substrates for SCD. These FA pairs were cis9-14:1/14:0, cis-9-16:1/16:0, cis-9-18:1/18:0, cis-9,trans11-18:2/trans-11-18:1. The normalized desaturase ratio was defined as [product of SCD]/[product of SCD + substrate of SCD]. Moreover, we also described the data obtained from the 2 experiments together during the experimental period by using principal component analysis (SAS Institute, 2000) with 72 individuals (5 
Table 3. Ingredient and nutrient intakes of diets (Experiment 1$)^{1}$

\begin{tabular}{|c|c|c|c|c|c|c|c|c|c|c|}
\hline \multirow[b]{2}{*}{ Item } & \multicolumn{5}{|c|}{ Diet } & \multicolumn{2}{|c|}{ Breed } & \multirow[b]{2}{*}{ SEM } & \multicolumn{2}{|c|}{$P$-value } \\
\hline & CONC & $\mathrm{CS}$ & $\mathrm{RS}$ & $\mathrm{RH}$ & NGH & Mo & $\mathrm{Ta}$ & & Diet & Breed \\
\hline \multicolumn{11}{|l|}{$\mathrm{DMI},{ }^{2} \mathrm{~kg} / \mathrm{d}$} \\
\hline Barley & $9.09^{\mathrm{a}}$ & $0.98^{\mathrm{b}}$ & $1.08^{\mathrm{b}}$ & $1.01^{\mathrm{b}}$ & $1.45^{\mathrm{b}}$ & 3.10 & 2.34 & 0.21 & $<0.01$ & $<0.01$ \\
\hline Soybean meal & $0.40^{\mathrm{a}}$ & $0.53^{\mathrm{b}}$ & $0.40^{\mathrm{a}}$ & $0.40^{\mathrm{a}}$ & $0.40^{\mathrm{a}}$ & 0.45 & 0.40 & 0.03 & 0.04 & 0.10 \\
\hline Urea & 0.10 & 0.30 & - & - & - & 0.20 & 0.20 & & & \\
\hline $\mathrm{CaCO}_{2}$ & 0.20 & 0.10 & - & - & - & 0.15 & 0.15 & & & \\
\hline \multicolumn{11}{|l|}{ Intake of fatty acids, $g / d$} \\
\hline 16:0 & $75^{\mathrm{a}}$ & $85^{\mathrm{bcd}}$ & $95^{\mathrm{cd}}$ & $76^{\mathrm{ab}}$ & $86^{c}$ & 90 & 77 & 3 & $<0.01$ & $<0.01$ \\
\hline Cis-9,cis-12-18:2 & $152^{\mathrm{b}}$ & $265^{\mathrm{c}}$ & $79^{\mathrm{a}}$ & $84^{\mathrm{a}}$ & $91^{\mathrm{a}}$ & 146 & 122 & 7 & $<0.01$ & $<0.01$ \\
\hline Cis-9,cis-12,cis-15-18:3 & $48^{\mathrm{b}}$ & $15^{\mathrm{a}}$ & $214^{\mathrm{c}}$ & $246^{\mathrm{d}}$ & $198^{\mathrm{c}}$ & 153 & 135 & 5 & $<0.01$ & $<0.01$ \\
\hline Sum of C18 fatty acid & $251^{\mathrm{a}}$ & $425^{\mathrm{e}}$ & $324^{\text {cd }}$ & $357^{\mathrm{d}}$ & $316^{\mathrm{bc}}$ & 360 & 309 & 14 & $<0.01$ & $<0.01$ \\
\hline Total fatty acids & $353^{\mathrm{a}}$ & $541^{\mathrm{d}}$ & $454^{\mathrm{bc}}$ & $480^{\mathrm{bc}}$ & $442^{\mathrm{b}}$ & 488 & 420 & 18 & $<0.01$ & $<0.01$ \\
\hline Energy intake,${ }^{4} \mathrm{MJ}$ of $\mathrm{NE} / \mathrm{d}$ & 91.7 & 92.5 & 85.2 & 95.7 & 93.6 & 99.1 & 84.4 & 3.8 & 0.44 & $<0.01$ \\
\hline \multicolumn{11}{|c|}{${ }^{a-d}$ Different letters within row indicate statistically significant difference between the means $(P<0.05)$. } \\
\hline \multicolumn{11}{|c|}{${ }^{1} \mathrm{CONC}=$ Concentrate $\mathrm{CS}=$ corn silage $; \mathrm{RS}=$ ryegrass silage $\mathrm{RH}=$ ryegrass hay; $\mathrm{NGH}=$ mountain natural grassland hay; $\mathrm{Mo}=$} \\
\hline \multicolumn{11}{|c|}{$\begin{array}{l}{ }^{1} \mathrm{CONC}=\text { Concentrate; } \mathrm{CS}=\text { corn silage; } \mathrm{RS}=\text { ryegrass silage; } \mathrm{RH}=\text { ryegrass hay; } \mathrm{NGH}=\text { mountain natural grassland hay; } \mathrm{Mo}= \\
\text { Montbéliarde cows; Ta = Tarentaise cows. }\end{array}$} \\
\hline \multicolumn{11}{|c|}{2 - = Not supplied. } \\
\hline \\
\hline \multicolumn{11}{|c|}{$\begin{array}{l}{ }^{3} \text { Minerals, \%: P, 8; Ca, 14; Mg, 10; Na, 0.7. Trace elements, mg/kg: Zn, 3,500; Mn, 2,200; Cu, 680; I, 27; Co, 6; Se, 4. Vitamins, IU/kg: A, } \\
\text { 200,000; D3, 40,000, E, 40. }\end{array}$} \\
\hline \multicolumn{11}{|l|}{${ }^{4} \mathrm{NE}=$ Net energy. } \\
\hline \multicolumn{11}{|c|}{${ }^{5} \mathrm{PDI}=$ Protein digestible in the intestine (INRA, 1989). } \\
\hline \multicolumn{11}{|c|}{${ }^{6}$ Balance $=$ Intake - maintenance and production requirements. } \\
\hline
\end{tabular}

diets with 8 cows and 2 diets with 8 cows and 2 periods) and 30 variables (milk fat percentage and yield, LPL activity, initial FFA, lipolysis, 4:0, 6:0, 8:0, 10:0, 10:1, $12: 0,13: 0,14: 0,14: 1$, iso-14, 15:0, iso-15, ante-15, 16:0, cis-9-16:1, iso-16, 17:0, 17:1, 18:0, cis-9-18:1, trans-1118:1, cis-9,trans-11-18:2, cis-9,trans-13-18:2, cis-9,cis12-18:2, cis-9,cis-12,cis-15-18:3 percentages). Furthermore, relationships between milk fat content or yield, and lipolytic system and milk selected FA were studied using correlation calculations (SAS Institute, 2000).

\section{RESULTS}

\section{DMI, Milk Yield, and Composition}

Experiment 1. The FA composition of feedstuffs is shown in Table 2 . The forages, except corn silage, were rich in linolenic acid. Some differences appeared between ryegrass silage and hay. The ryegrass silage had lower linoleic and linolenic acid contents than ryegrass hay. Data on ingredient intake, DMI, and energy balance for each treatment are shown in Table 3. Forage, barley and soybean meal, and total DMI differed among diets, but energy intake and balance were similar, according to the experimental design. Cows fed RS consumed $15 \%$ less DM than did cows fed the other diets due to the initial overestimation of the nutritional value of grass silage. The PDI intake was lowest for CS and $\mathrm{RS}$ diets. The cows fed the NGH diet had the highest PDI intake.

Milk yield and composition are shown in Table 4 . The highest milk production was observed for the cows fed the $\mathrm{RH}$ diet. The highest $(P<0.01)$ milk fat content was observed for the CONC and CS diets and the lowest milk fat content for RS diets. The lowest milk fat yield was observed for the RS diet. The CONC group had the highest milk protein content. The milk protein yield varied from 0.41 to $0.50 \mathrm{~kg} / \mathrm{d}$ for $\mathrm{RS}, \mathrm{CONC}$, and $\mathrm{RH}$ groups, respectively. Diet had no effect on milk calcium content. Milk phosphorus varied from 0.82 to $0.98 \mathrm{~g} / \mathrm{kg}$ for $\mathrm{RS}$ and CONC diets, respectively $(P<0.05)$. The CS and NGH groups had $(P<0.05)$ the highest milk urea content compared with the other groups.

The Tarentaise cows had lower DM, net energy, fatty acid, and PDI intake $(P<0.01)$ than the Montbéliarde cows (Table 3). The Montbéliarde cows had higher milk production $(+29 \%, P<0.01$; Table 4$)$, milk fat content $(P=0.05)$ and yield, and protein yield $(P<0.01)$ than the Tarentaise cows, whereas their milk protein and phosphorus contents were lower $(P<0.01)$.

Experiment 2. The grazed grass at $3 \mathrm{wk}$ had lower linoleic acid content than at $6 \mathrm{wk}$ (Table 2). The linolenic 
Table 4. Effect of nature of forages and cow breed on milk yield and milk composition (Experiment 1$)^{1}$

\begin{tabular}{|c|c|c|c|c|c|c|c|c|c|c|}
\hline \multirow[b]{2}{*}{ Item } & \multicolumn{5}{|c|}{ Diet } & \multicolumn{2}{|c|}{ Breed } & \multirow[b]{2}{*}{ SEM } & \multicolumn{2}{|c|}{$P$-value } \\
\hline & CONC & CS & $\mathrm{RS}$ & $\mathrm{RH}$ & NGH & Mo & $\mathrm{Ta}$ & & Diet & Breed \\
\hline Milk, kg/d & $13.8^{\mathrm{a}}$ & $14.2^{\mathrm{a}}$ & $13.5^{\mathrm{a}}$ & $16.0^{\mathrm{b}}$ & $14.6^{\mathrm{a}}$ & 16.9 & 12.0 & 0.4 & $<0.01$ & $<0.01$ \\
\hline $\begin{array}{l}\text { Fat } \\
\mathrm{g} / \mathrm{kg} \\
\mathrm{kg} / \mathrm{d}\end{array}$ & $\begin{array}{c}40.4^{\mathrm{c}} \\
0.55^{\mathrm{b}}\end{array}$ & $\begin{array}{r}38.6^{\mathrm{bc}} \\
0.54^{\mathrm{b}}\end{array}$ & $\begin{array}{c}34.1^{\mathrm{a}} \\
0.45^{\mathrm{a}}\end{array}$ & $\begin{array}{r}36.8^{\mathrm{ab}} \\
0.59^{\mathrm{b}}\end{array}$ & $\begin{array}{c}37.1^{\mathrm{b}} \\
0.54^{\mathrm{b}}\end{array}$ & $\begin{array}{c}38.3 \\
0.64\end{array}$ & $\begin{array}{c}36.6 \\
0.43\end{array}$ & $\begin{array}{l}0.9 \\
0.02\end{array}$ & $\begin{array}{l}<0.01 \\
<0.01\end{array}$ & $\begin{array}{r}0.05 \\
<0.01\end{array}$ \\
\hline $\begin{array}{l}\text { Protein } \\
\text { g/kg } \\
\mathrm{kg} / \mathrm{d}\end{array}$ & $\begin{array}{c}35.9^{\mathrm{b}} \\
0.50^{\mathrm{c}}\end{array}$ & $\begin{array}{c}31.9^{\mathrm{a}} \\
0.44^{\mathrm{ab}}\end{array}$ & $\begin{array}{c}30.7^{\mathrm{a}} \\
0.41^{\mathrm{a}}\end{array}$ & $\begin{array}{c}32.0^{\mathrm{a}} \\
0.50^{\mathrm{c}}\end{array}$ & $\begin{array}{c}32.4^{\mathrm{a}} \\
0.47^{\mathrm{bc}}\end{array}$ & $\begin{array}{c}31.5 \\
0.53\end{array}$ & $\begin{array}{c}33.6 \\
0.40\end{array}$ & $\begin{array}{l}0.7 \\
0.02\end{array}$ & $\begin{array}{r}<0.01 \\
0.01\end{array}$ & $\begin{array}{l}<0.01 \\
<0.01\end{array}$ \\
\hline $\begin{array}{l}\text { Urea, mg/L } \\
\text { Calcium, g/kg } \\
\text { Phosphorus, g/kg }\end{array}$ & $\begin{array}{l}0.25^{\mathrm{a}} \\
1.15 \\
0.98^{\mathrm{c}}\end{array}$ & $\begin{array}{l}0.40^{\mathrm{bc}} \\
1.13 \\
0.94^{\mathrm{bc}}\end{array}$ & $\begin{array}{l}0.29^{\mathrm{ab}} \\
1.01 \\
0.82^{\mathrm{a}}\end{array}$ & $\begin{array}{l}0.27^{\mathrm{a}} \\
1.08 \\
0.86^{\mathrm{ab}}\end{array}$ & $\begin{array}{l}0.45^{\mathrm{c}} \\
1.03 \\
0.85^{\mathrm{ab}}\end{array}$ & $\begin{array}{l}0.32 \\
1.04 \\
0.84\end{array}$ & $\begin{array}{l}0.34 \\
1.12 \\
0.93\end{array}$ & $\begin{array}{l}0.04 \\
0.05 \\
0.04\end{array}$ & $\begin{array}{r}<0.01 \\
0.23 \\
0.02\end{array}$ & $\begin{array}{l}0.61 \\
0.09 \\
0.01\end{array}$ \\
\hline
\end{tabular}

${ }^{\mathrm{a}-\mathrm{c}}$ Different letters within row indicate statistically significant difference between the means $(P<0.05)$.

${ }^{1} \mathrm{CONC}=$ Concentrate $\mathrm{CS}=$ corn silage; $\mathrm{RS}=$ ryegrass silage; $\mathrm{RH}=$ ryegrass hay; $\mathrm{NGH}=$ mountain natural grassland hay; Mo = Montbéliarde cows; Ta = Tarentaise cows. Data were least squares means.

acid content ranked by forages was PAS3 > NGH > PAS6. For the NGH diet, forage intake, DMI, energy and PDI intake, and energy balance were higher at wk 6 than at wk 3 (Table 5). Intake of cis-9,cis-12-18:2, cis9,cis-12,cis-15-18:3, sum of C18 FA, and total FA was higher at wk 6 than at wk 3. The variation in BW differed between diets: the decrease in BW for the PAS diet was higher at wk 3 than at wk 6 , whereas the increase in BW for NGH diet was greater at wk 6 than at wk 3. Milk yield, fat yield, protein content, and yield were higher at wk 3 than at wk 6 (Table 6). The NGH diet induced milk with higher protein, urea, and phosphorus contents than the PAS diet.

The Tarentaise cows had lower DM, net energy, PDI, and fatty acid intakes $(P<0.01)$ than the Montbéliarde cows (Table 5). The Montbéliarde cows had higher milk production $(+54 \%, P<0.01$; Table 6$)$, milk fat and protein yields $(P<0.01)$ than the Tarentaise cows, whereas their milk protein, calcium, and phosphorus contents were lower $(P<0.01)$.

\section{Blood Plasma Metabolite and Insulin Concentrations}

Experiment 1. The diet effect was significant $(P<$ 0.01 ) on plasma metabolites (Table 7), except for plasma NEFA and insulinemia. The highest and second highest values of plasma BHBA were observed for the CS and RS diets, respectively. Plasma urea varied from 211 to $433 \mathrm{mg} / \mathrm{L}$ for the RS and NGH diets, respectively. In cows fed the NGH diet, plasma glucose concentration tended to be lower and averaged $576 \mathrm{mg} / \mathrm{L}$ compared with other diets $(625 \mathrm{mg} / \mathrm{L})$. The Tarentaise cows had higher plasma glycemia $(P<0.01)$ and insulinemia $(P=$ $0.02)$ than the Montbéliarde cows. Milk urea was highly related to plasma urea $(\mathrm{r}=0.69 ; P<0.01)$.
Experiment 2. Plasma NEFA and BHBA were increased by the PAS6 diet (Table 8). Plasma urea and insulinemia were decreased by the PAS6 diet; plasma glucose concentration tended to be lower with PAS6 than with NGH6 diets. The Tarentaise cows had higher plasma glycemia $(P=0.02)$ and insulinemia $(P=0.01)$ than the Montbéliarde cows.

\section{Milk Fatty Acid Composition}

Preexperiment. During the preexperimental periods, the Montbéliarde cows had much higher milk percentage of $16: 0(+3.4 \mathrm{~g} / 100 \mathrm{~g}, P<0.01)$ and lower percentages of $18: 0(-0.95 \mathrm{~g} / 100 \mathrm{~g}, P=0.02)$ and cis-9,cis12,cis-15-18:3 ( $-0.18 \mathrm{~g} / 100 \mathrm{~g}, P=0.04)$ than Tarentaise cows (Table 9). The Montbéliarde cows tended to have higher atherogenicity index $(+11 \%, P=0.06)$ than the Tarentaise cows. The desaturase index for cis-9-16:1 was lower $(P=0.05)$ for Montbéliarde than for Tarentaise cows.

Experiment 1. The FA composition of milk fat is presented in Table 10. Diet had significant effects on milk FA composition, except for 4:0 and sum of $6: 0$ and 8:0. The sum of 10:0, 12:0, and 14:0 tended to be lowest for RS group and was highest for cows fed the CONC $\operatorname{diet}(P=0.06)$. Feeding NGH diet reduced the percentage of 16:0, whereas feeding the CONC diet increased it. The stearic and oleic acid percentages were lowest for the CONC diet. The lowest values for the cis-9,trans11-18:2 percentage were obtained with CONC and RS diets. This percentage increased 2.05-fold when cows consumed the RH diet. Similarly, the trans-11-18:1 percentage was lowest for the CONC diet and highest (3fold) for the RH diet. The cis-9,cis-12-18:2 percentage was reduced by the RS, $\mathrm{RH}$, and NGH diets and was increased by the CONC diet, as was its yield. In con- 
Table 5. Ingredient and nutrient intakes of diets (Experiment 2)

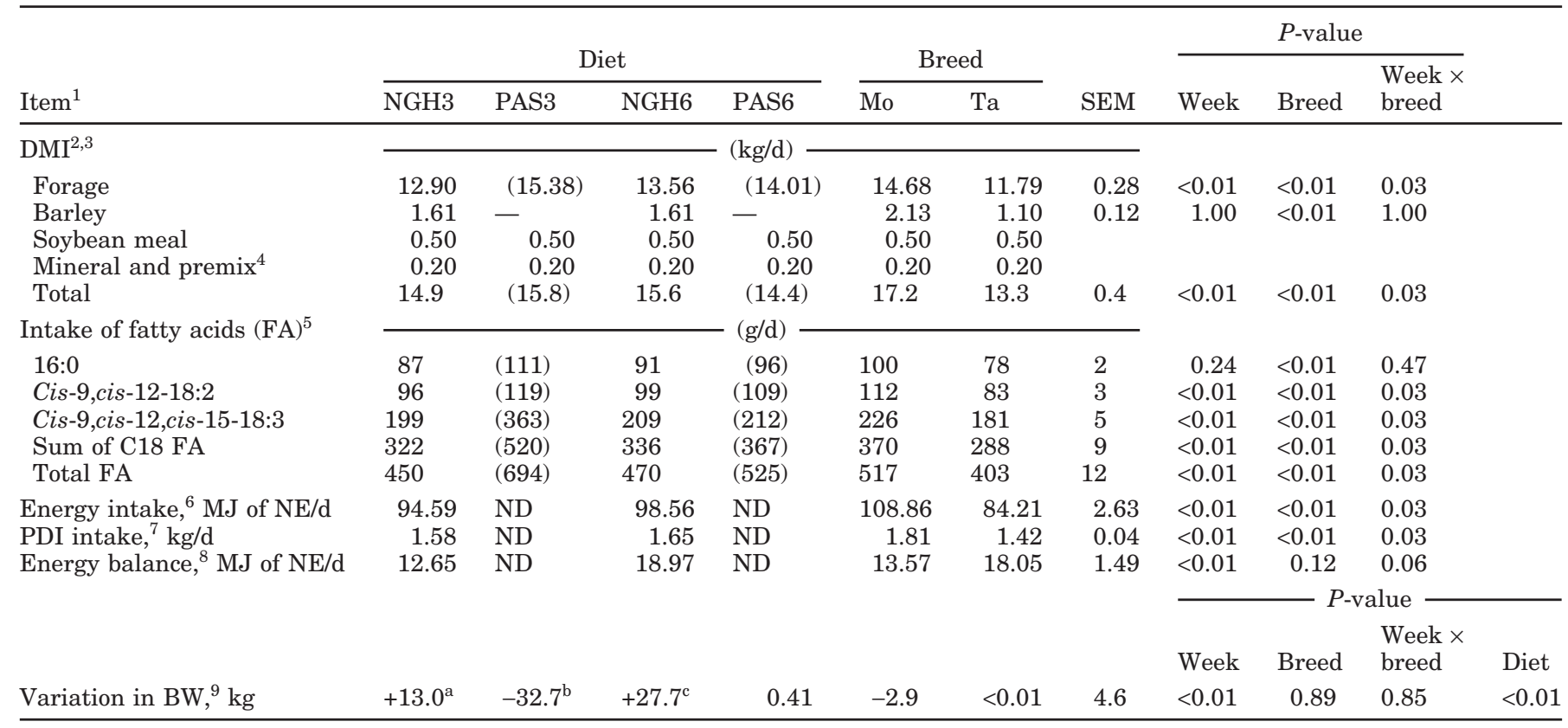

${ }^{a-c}$ Different letters within row indicate statistically significant difference between the means $(P<0.05)$.

${ }^{1}$ NGH3 or NGH6 = mountain natural grassland hay fed at 3 or 6 wk, respectively; PAS3 or PAS6 = pasture at 3 or 6 wk, respectively; Mo $=$ Montbéliarde cows; $\mathrm{Ta}=$ Tarentaise cows.

${ }^{2}-=$ Not supplied.

${ }^{3}$ DM intake for PAS3 and PAS6 diets was estimated from INRA (1989) and are given in parentheses. Data were only analyzed for NGH diet.

${ }^{4}$ Minerals, \%: P, 8; Ca, 14; Mg, 10; Na, 0.7. Trace elements, mg/kg: Zn, 3,500; Mn, 2,200; Cu, 680; I, 27; Co, 6; Se, 4. Vitamins, IU/kg: A, 200,$000 ; \mathrm{D}_{3}, 40,000, \mathrm{E}, 40$.

${ }^{5} \mathrm{FA}$ intake estimates are given in parentheses.

${ }^{6} \mathrm{NE}=$ Net energy; $\mathrm{ND}=$ not determined.

${ }^{7} \mathrm{PDI}=$ Protein digestible in the intestine (INRA, 1989).

${ }^{8}$ Balance $=$ Intake - maintenance and production requirements.

${ }^{9}$ Variations between the end of the preexperimental period and the end of the experimental period.

Table 6. Effect of week, nature of forages, and cow breed on milk yield and milk composition (Experiment 2)

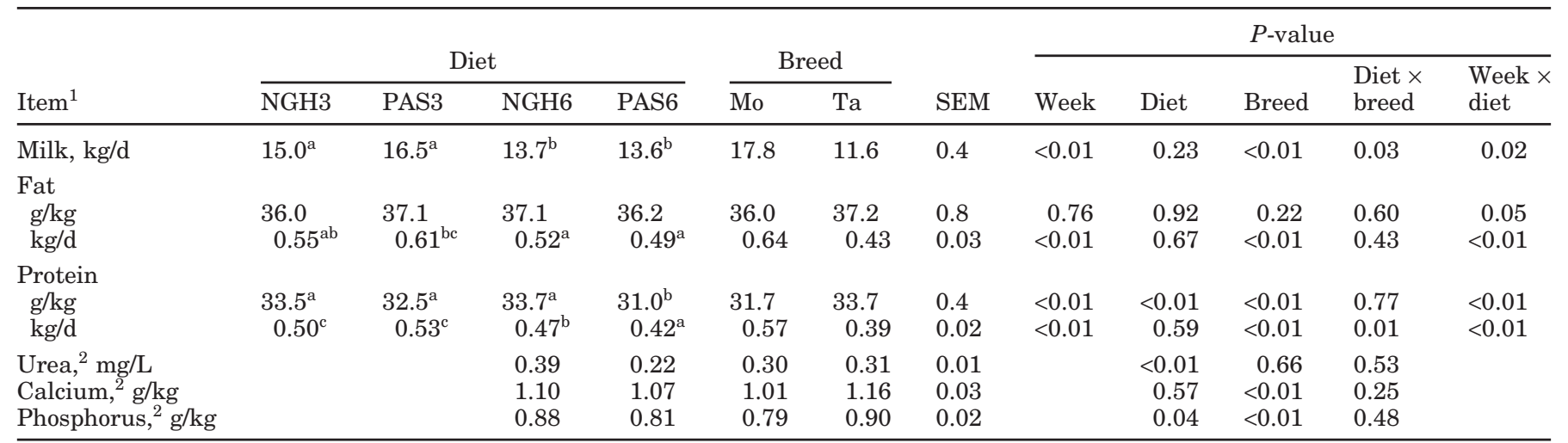

${ }^{\mathrm{a}, \mathrm{b}}$ Different letters within row indicate statistically significant difference between the means $(P<0.05)$.

${ }^{1}$ NGH3 or NGH6 = mountain natural grassland hay fed at 3 or 6 wk, respectively; PAS3 or PAS6 = pasture at 3 or 6 wk, respectively; Mo = Montbéliarde cows; Ta $=$ Tarentaise cows. Data were least square means.

${ }^{2}$ Not determined during pasture at $3 \mathrm{wk}$. 
Table 7. Effect of nature of forages and cow breed on plasma metabolites and insulin (Experiment 1)

\begin{tabular}{|c|c|c|c|c|c|c|c|c|c|c|}
\hline \multirow[b]{2}{*}{ Item $^{1}$} & \multicolumn{5}{|c|}{ Diet } & \multicolumn{2}{|c|}{ Breed } & \multirow[b]{2}{*}{ SEM } & \multicolumn{2}{|c|}{$P$-value } \\
\hline & CONC & CS & $\mathrm{RS}$ & $\mathrm{RH}$ & $\mathrm{NGH}$ & Mo & $\mathrm{Ta}$ & & Diet & Breed \\
\hline NEFA, $\mu M$ & 39 & 29 & 52 & 52 & 34 & 33 & 49 & 12 & 0.55 & 0.13 \\
\hline BНBA, $\mu M$ & $508^{\mathrm{a}}$ & $682^{\mathrm{b}}$ & $694^{\mathrm{b}}$ & $450^{\mathrm{a}}$ & $489^{\mathrm{a}}$ & 605 & 524 & 54 & $<0.01$ & 0.11 \\
\hline Urea, mg/L & $225^{\mathrm{a}}$ & $378^{\mathrm{c}}$ & $211^{\mathrm{a}}$ & $281^{\mathrm{b}}$ & $433^{\mathrm{d}}$ & 292 & 313 & 14 & $<0.01$ & 0.10 \\
\hline Glucose, mg/L & 621 & 640 & 629 & 610 & 576 & 591 & 639 & 15 & 0.07 & $<0.01$ \\
\hline Insulin, $\mu \mathrm{IU} / \mathrm{mL}$ & 16.0 & 18.7 & 20.7 & 16.4 & 14.7 & 14.0 & 20.6 & 2.9 & 0.76 & 0.02 \\
\hline
\end{tabular}

${ }^{\mathrm{a}-\mathrm{d}}$ Different letters within row indicate statistically significant difference between the means $(P<0.05)$.

${ }^{1} \mathrm{CONC}=$ Concentrate; $\mathrm{CS}=$ corn silage; $\mathrm{RS}=$ ryegrass silage; $\mathrm{RH}=$ ryegrass hay; $\mathrm{NGH}=$ mountain natural grassland hay; Mo = Montbéliarde cows; Ta $=$ Tarentaise cows. Data were least squares means.

Table 8. Effect of nature of forages and cow breed on plasma metabolites and insulin (Experiment 2)

\begin{tabular}{|c|c|c|c|c|c|c|c|}
\hline \multirow[b]{2}{*}{ Item $^{1}$} & \multicolumn{2}{|c|}{ Diet } & \multicolumn{2}{|c|}{ Breed } & \multirow[b]{2}{*}{ SEM } & \multicolumn{2}{|c|}{$P$-value } \\
\hline & NGH6 & PAS6 & Mo & $\mathrm{Ta}$ & & Diet & Breed \\
\hline NEFA, $\mu M$ & 35 & 99 & 52 & 82 & 14 & $<0.01$ & 0.16 \\
\hline BHBA, $\mu M$ & 468 & 933 & 649 & 753 & 88 & $<0.01$ & 0.42 \\
\hline Urea, mg/L & 405 & 183 & 284 & 305 & 11 & $<0.01$ & 0.21 \\
\hline Glucose, mg/L & 623 & 587 & 582 & 628 & 12 & 0.10 & 0.02 \\
\hline Insulin, $\mu \mathrm{IU} / \mathrm{mL}$ & 20.82 & 11.75 & 14.09 & 18.47 & 1.1 & $<0.01$ & 0.01 \\
\hline
\end{tabular}

${ }^{1}$ NGH6 = Mountain natural grassland hay fed at 6 wk; PAS6 = pasture at 6 wk; Mo = Montbéliarde cows; $\mathrm{Ta}=$ Tarentaise cows. Data were least squares means.

Table 9. Effects of cow breed on milk fatty acid percentages, atherogenicity and desaturase indexes in preexperimental period

\begin{tabular}{|c|c|c|c|c|c|}
\hline \multirow[b]{2}{*}{ Item $^{1}$} & \multicolumn{2}{|c|}{ Breed } & \multirow[b]{2}{*}{ SEM } & \multicolumn{2}{|c|}{$P$-value } \\
\hline & Mo & $\mathrm{Ta}$ & & Breed & Experiment \\
\hline Fatty acid & \multicolumn{5}{|c|}{$-(\mathrm{g} / 100 \mathrm{~g}$ of fatty acids $)-$} \\
\hline $4: 0$ & 4.07 & 3.78 & 0.14 & 0.18 & $<0.01$ \\
\hline $6: 0+8: 0$ & 3.97 & 3.88 & 0.12 & 0.63 & $<0.01$ \\
\hline $10: 0+12: 0+14: 0$ & 18.59 & 18.95 & 0.47 & 0.62 & $<0.01$ \\
\hline $16: 0$ & 33.03 & 29.63 & 0.65 & $<0.01$ & $<0.01$ \\
\hline $18: 0^{2}$ & 7.96 & 8.91 & 0.26 & 0.02 & $<0.01$ \\
\hline Cis-9-18:1 & 16.85 & 17.88 & 0.48 & 0.18 & $<0.01$ \\
\hline Trans-11-18:1 & 1.41 & 1.52 & 0.09 & 0.48 & $<0.01$ \\
\hline Cis-9,cis-12-18:2 & 1.29 & 1.41 & 0.04 & 0.08 & $<0.01$ \\
\hline Cis-9,trans-13-18:2 & 0.18 & 0.20 & 0.01 & 0.14 & 0.71 \\
\hline Cis-9,cis-12,cis-15-18:3 & 0.58 & 0.76 & 0.05 & 0.04 & $<0.01$ \\
\hline Cis-9,trans-11-18:2 & 0.71 & 0.73 & 0.05 & 0.84 & 0.05 \\
\hline Atherogenicity index ${ }^{3}$ & 3.51 & 3.13 & 0.12 & 0.06 & $<0.01$ \\
\hline \multicolumn{6}{|l|}{ Desaturase index ${ }^{4}$} \\
\hline Cis-9-14:1 & 0.069 & 0.074 & 0.003 & 0.25 & 0.30 \\
\hline Cis-9-16:1 & 0.047 & 0.053 & 0.002 & 0.05 & $<0.01$ \\
\hline Cis-9-18:1 & 0.677 & 0.668 & 0.007 & 0.42 & 0.99 \\
\hline Cis-9,trans-11-18:2 & 0.557 & 0.539 & 0.007 & 0.12 & $<0.01$ \\
\hline
\end{tabular}

${ }^{1} \mathrm{Mo}=$ Montbéliarde cows; $\mathrm{Ta}=$ Tarentaise cows (for each breed, $\mathrm{n}=28$ ). Data were least squares means.

${ }^{2}$ Breed $\times$ experiment interaction, $P=0.05$.

${ }^{3}$ Atherogenicity index $=(12: 0+4 \times 14: 0+16: 0)$ : (sum of unsaturated fatty acids $)$ (Ulbricht and Southgate, 1991).

${ }^{4}$ Expressed as [product of stearoyl-coenzyme A desaturase (SCD)]/[product of SCD+ substrate of SCD]. 
Table 10. Effects of nature of forages and cow breed on milk fatty acid (FA) percentages and yield, atherogenicity and desaturase indexes, and transfer efficiencies (Experiment 1)

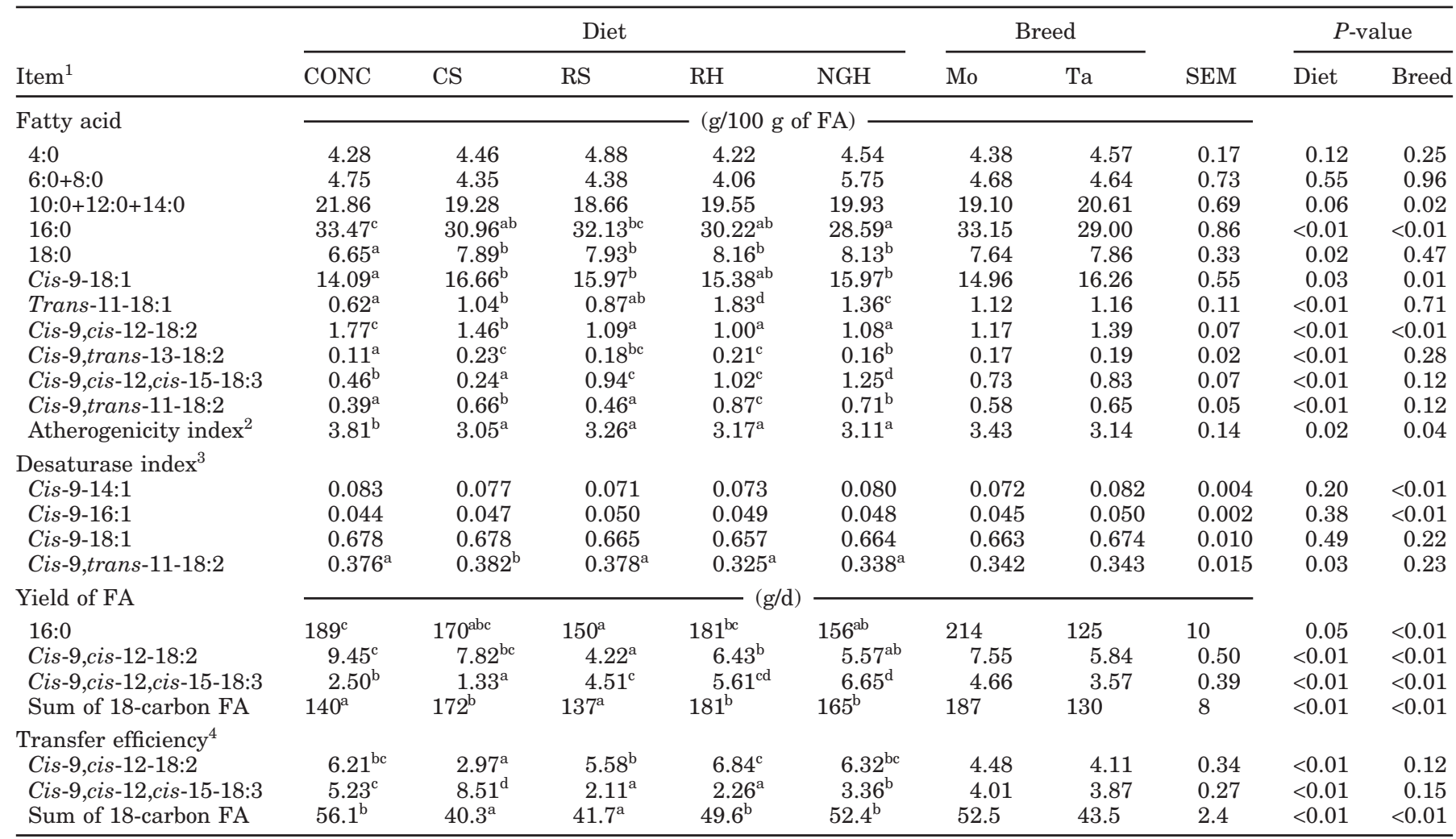

${ }^{\mathrm{a}-\mathrm{d}}$ Different letters within row indicate statistically significant difference between the means $(P<0.05)$.

${ }^{1} \mathrm{CONC}=$ Concentrate CS = corn silage; $\mathrm{RS}=$ ryegrass silage; $\mathrm{RH}=$ ryegrass hay; $\mathrm{NGH}=$ mountain natural grassland hay; $\mathrm{Mo}=$ Montbéliarde cows; $\mathrm{Ta}=$ Tarentaise cows. Data were least squares means.

${ }^{2}$ Atherogenicity index $=(12: 0+4 \times 14: 0+16: 0)$ : Sum of unsaturated fatty acids) (Ulbricht and Southgate, 1991).

${ }^{3}$ Expressed as [product of stearoyl-coenzyme A desaturase (SCD)]/[product of SCD+ substrate of SCD].

${ }^{4}$ Expressed as (FA yielded/FA intake).

trast, the RS diet reduced yield of cis-9,cis-12-18:2. The cis-9,cis-12,cis-15-18:3 percentage and yield were decreased by the CONC and CS diets, whereas its yield was increased by the NGH diet. Milk yield of FA with 18 carbons was higher for the $\mathrm{CS}, \mathrm{RH}$, and NGH diets than for other diets. The atherogenicity index [(12:0 + $4 \times 14: 0+16: 0) /($ sum of unsaturated fatty acids)] was highest for the cows fed the CONC diet. The CS diet increased the desaturase index for cis-9,trans-11-18:2 (Table 10), although the other diets decreased it. Transfer efficiencies from intake to milk of cis-9,cis-12-18:2, cis-9,cis-12,cis-15-18:3, and sum of 18-carbon FA were $5.6,4.3$, and $48.0 \%$, respectively. Transfer efficiency of cis-9,cis-12-18:2 was lower with the CS diet and higher with the $\mathrm{RH}$ diet. The transfer efficiency of cis-9,cis12,cis-15-18:3 was lower with the RS diet and higher with the CS diet. Transfer efficiency of sum of 18-carbon FA was lowest for the CS and RS diets and highest for other diets.
The Montbéliarde cows had a much higher percentage of 16:0 and lower percentage of sum of 10:0 to 14:0 FA, cis-9-18:1, and cis-9,cis-12-18:2 than the Tarentaise cows (Table 10). The atherogenicity index was $9 \%$ lower $(P<0.01)$ for the Tarentaise than for the Montbéliarde cows. The Montbéliarde cows had a lower desaturase index for $c i s-9-14: 1$ and cis-9-16:1 than Tarentaise cows. Transfer efficiency of sum of 18-carbon FA from intake to milk was higher $(P<0.01)$ for Montbéliarde than for Tarentaise cows.

Experiment 2. The percentages of sum of 6:0 and 8:0, and sum of $10: 0$ to $14: 0,16: 0$, and cis-9,cis-12,cis15-18:3 were lower for grazing cows than for cows fed the NGH diet (Table 11). Feeding the PAS diet increased the percentages of $c i s-9-18: 1$, trans-11-18:1, cis9,trans-13-18:2, and cis-9,trans-11-18:2. The atherogenicity index was lower $(P<0.01)$ for the grazing cows than for the cows fed the NGH diet. This latter diet decreased the desaturase indexes for cis-9-16:1 and cis- 
Table 11. Effects of week, nature of forages and cow breed on milk fatty acid percentages and yield, atherogenicity and desaturase indexes, and transfer efficiencies (Experiment 2)

\begin{tabular}{|c|c|c|c|c|c|c|c|c|c|c|c|c|}
\hline \multirow[b]{3}{*}{ Item $^{1}$} & \multirow{2}{*}{\multicolumn{4}{|c|}{ Diet }} & \multirow{2}{*}{\multicolumn{2}{|c|}{ Breed }} & \multirow[b]{3}{*}{ SEM } & \multicolumn{5}{|c|}{$P$-value } \\
\hline & & & & & & & & & & & Diet $x$ & Week $x$ \\
\hline & NGH3 & PAS3 & NGH6 & PAS6 & Mo & $\mathrm{Ta}$ & & Week & Diet & Breed & breed & diet \\
\hline $4: 0$ & 3.00 & 3.23 & 3.49 & 3.37 & 3.30 & 3.24 & 0.15 & 0.04 & 0.80 & 0.75 & 0.29 & 0.24 \\
\hline $6: 0+8: 0$ & 3.43 & 2.81 & 3.60 & 3.10 & 3.15 & 3.32 & 0.13 & 0.07 & $<0.01$ & 0.27 & 0.06 & 0.63 \\
\hline $10: 0+12: 0+14: 0$ & 19.61 & 14.82 & 18.79 & 16.48 & 17.61 & 17.24 & 0.80 & 0.54 & 0.04 & 0.67 & 0.11 & 0.08 \\
\hline $16: 0$ & 28.12 & 22.86 & 31.69 & 29.63 & 29.78 & 26.37 & 0.90 & $<0.01$ & $<0.01$ & 0.01 & $<0.01$ & 0.09 \\
\hline Trans-11-18:1 & $1.26^{\mathrm{a}}$ & $3.69^{\mathrm{b}}$ & $1.27^{\mathrm{a}}$ & $1.75^{\mathrm{a}}$ & 2.16 & 1.82 & 0.22 & $<0.01$ & $<0.01$ & 0.23 & 0.04 & $<0.01$ \\
\hline Cis-9,cis-12-18:2 & 1.03 & 1.09 & 1.35 & 1.23 & 1.05 & 1.30 & 0.06 & $<0.01$ & 0.68 & $<0.01$ & 0.34 & 0.21 \\
\hline Cis-9,trans-13-18:2 & $0.16^{\mathrm{a}}$ & $0.24^{\mathrm{b}}$ & $0.18^{\mathrm{a}}$ & $0.16^{\mathrm{a}}$ & 0.18 & 0.18 & 0.01 & $<0.01$ & 0.03 & 0.99 & 0.26 & $<0.01$ \\
\hline Cis-9,cis-12,cis-15-18:3 & $1.72^{\mathrm{a}}$ & $0.99^{\mathrm{b}}$ & $0.80^{\mathrm{b}}$ & $0.68^{\mathrm{b}}$ & 0.90 & 1.20 & 0.09 & $<0.01$ & $<0.01$ & $<0.01$ & $<0.01$ & 0.05 \\
\hline Cis-9,trans-11-18:2 & $0.62^{\mathrm{a}}$ & $1.72^{\mathrm{b}}$ & $0.58^{\mathrm{a}}$ & $0.80^{\mathrm{a}}$ & 1.06 & 0.81 & 0.10 & $<0.01$ & $<0.01$ & 0.05 & $<0.01$ & $<0.01$ \\
\hline Atherogenicity index ${ }^{2}$ & 2.97 & 1.64 & 3.19 & 2.40 & 2.79 & 2.31 & 0.20 & 0.01 & $<0.01$ & 0.08 & 0.01 & 0.14 \\
\hline \multicolumn{13}{|l|}{ Yield of fatty acids } \\
\hline $16: 0$ & 157 & 143 & 172 & 147 & 195 & 114 & 11 & 0.20 & 0.24 & $<0.01$ & 0.37 & 0.42 \\
\hline Cis-9,cis-12-18:2 & $5.49^{\mathrm{a}}$ & $6.48^{\mathrm{ab}}$ & $6.92^{\mathrm{b}}$ & $5.73^{\mathrm{a}}$ & 6.75 & 5.57 & 0.46 & 0.46 & 0.87 & 0.07 & $<0.01$ & 0.03 \\
\hline Cis-9,cis-12,cis-15-18:3 & 8.78 & 6.11 & 3.50 & 3.44 & 5.84 & 5.08 & 0.57 & $<0.01$ & 0.05 & 0.21 & 0.58 & 0.14 \\
\hline \multirow[t]{2}{*}{ Sum of 18-carbon FA } & $189^{\mathrm{a}}$ & $277^{\mathrm{b}}$ & $166^{\mathrm{a}}$ & $180^{\mathrm{a}}$ & 231 & 175 & 14 & $<0.01$ & 0.03 & 0.01 & 0.85 & $<0.01$ \\
\hline & & & & & & & & \multicolumn{5}{|c|}{$\longrightarrow P$-value -} \\
\hline \multicolumn{8}{|l|}{ Transfer efficiency ${ }^{4}$} & Week & Breed & & & \\
\hline Cis-9,cis-12-18:2 & 5.68 & $(5.46)$ & 6.83 & $(5.32)$ & 6.27 & 6.24 & 5.70 & 0.17 & 0.98 & & & \\
\hline Cis-9,cis-12,cis-15-18:3 & 4.42 & (1.69) & 1.69 & $(1.63)$ & 2.86 & 3.26 & 4.20 & $<0.01$ & 0.52 & & & \\
\hline Sum of 18-carbon FA & 57.8 & $(53.7)$ & 48.4 & $(49.4)$ & 55.4 & 50.8 & 3.4 & 0.03 & 0.41 & & & \\
\hline
\end{tabular}

${ }^{\mathrm{a}, \mathrm{b}}$ Different letters within row indicate statistically significant difference between the means (week $\times$ diet interaction, $P<0.05$ ).

${ }^{1} \mathrm{NGH} 3$ or NGH6 = mountain natural grassland hay fed at 3 or $6 \mathrm{wk}$, respectively; PAS3 or PAS6 = pasture at 3 or 6 wk, respectively; Mo $=$ Montbéliarde cows; $\mathrm{Ta}=$ Tarentaise cows. Data were least squares means.

${ }^{2}$ Atherogenicity index $=(12: 0+4 \times 14: 0+16: 0)$ : (sum of unsaturated fatty acids) (Ulbricht and Southgate, 1991).

${ }^{3}$ Expressed as [product of stearoyl-coenzyme A desaturase (SCD)]/[product of SCD+ substrate of SCD].

${ }^{4}$ Expressed as (FA yielded/FA intake). FA intake for PAS3 and PAS6 diets was estimated from INRA (1989). Data were only analyzed for NGH diet.

9-18:1. Yield of cis-9,cis-12,cis-15-18:3 was lower for the PAS diet than for the NGH diet, whereas the yield of sum of 18-carbon FA was higher for the PAS than for the NGH diet.

The Montbéliarde cows had much higher percentages of 16:0 and higher cis-9,trans-11-18:2 and lower percentages of 18:0, cis-9,cis-12-18:2, and cis-9,cis-12,cis15-18:3 than the Tarentaise cows (Table 11). For the NGH diet, Montbéliarde cows produced milk with higher 16:0 (33.6 vs. $26.2 \mathrm{~g} / 100 \mathrm{~g}$ ) and lower cis-9-18:1 (16.0 vs. $20.1 \mathrm{~g} / 100 \mathrm{~g})$ and cis-9,cis-12,cis-15-18:3 (0.9 vs. $1.6 \mathrm{~g} / 100 \mathrm{~g}$ ) percentages than Tarentaise cows (diet $\times$ breed interaction, Table 11 and Figure 1). For the PAS diet, Montbéliarde cows had higher percentages of trans-11-18:1 and cis-9,trans-11-18:2 than Tarentaise cows. Yield of 16:0 and sum of 18-carbon FA was higher with Montbéliarde than with Tarentaise cows (Table
11). The Montbéliarde cows had higher desaturase index for cis-9-18: 1 than Tarentaise cows ( 0.685 vs. 0.663 ; $P=0.02)$.

\section{Principal Component Analysis}

Two significant principal components (PC) could be extracted describing $31 \%$ (PC1) and 16\% (PC2) of the total variation in milk fat content, fat yield, FA composition, and milk lipolytic system when all data from Experiments 1 and 2 were pooled (Figure 2). The PC1 (Figure 2A) opposed 2 families of FA. The short- and medium-chain FA (4:0 to 14:1) come together in one cluster, except for 8:0. In opposition, long-chain FA (17:1, 18:0, cis-9-18:1, trans-11-18:1, cis-9,trans-1118:2) are located in the second cluster. The PC2 (Figure 2A) separated the branched-chain (BC) and odd-num- 
16:0

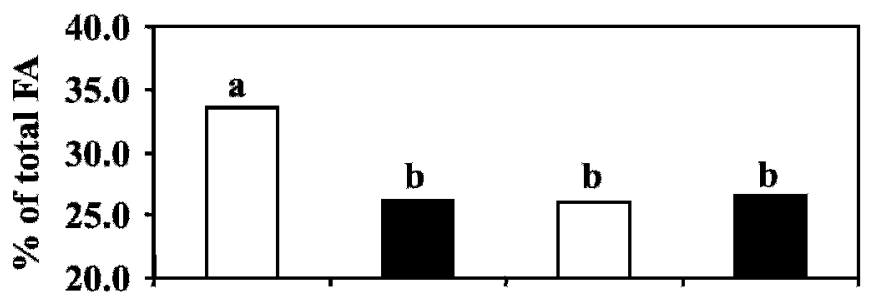

cis9-18:1

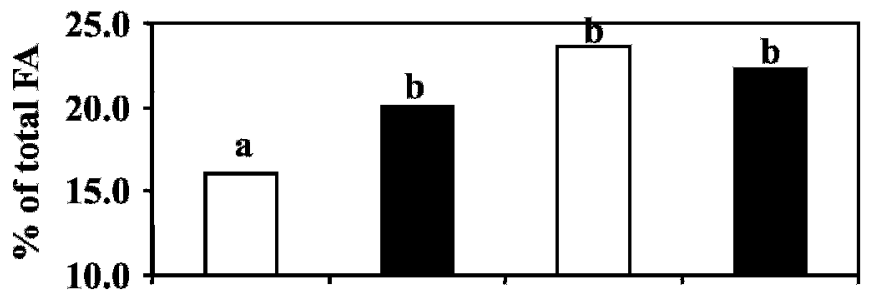

cis9,cis12,cis15-18:3

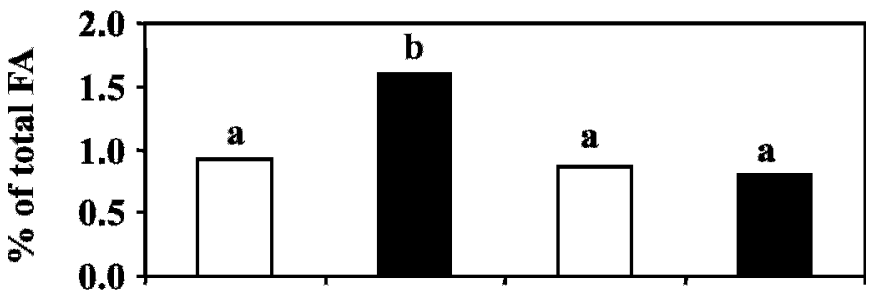

cis9,trans11-18:2

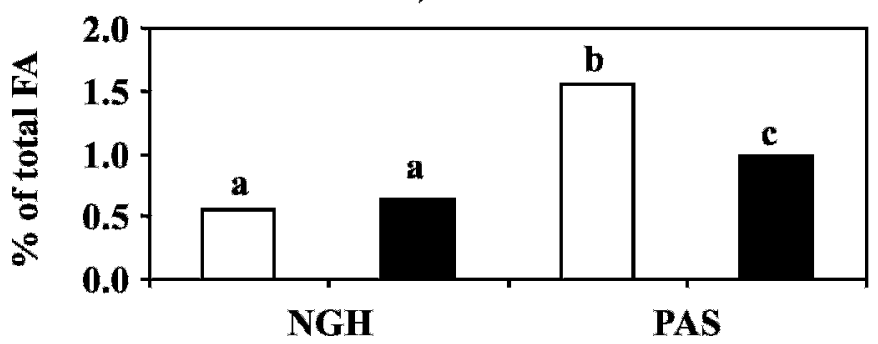

Figure 1. Effects of interaction between diet and breed on milk percentages of 16:0, cis-9-18:1, cis-9,cis-12,cis-15-18:3, and cis9,trans-11-18:2 in Montbéliarde ( $\square$ ) and Tarentaise ( $\square$ ) cows (Experiment 2). Data are least squares means. ${ }^{a-c}$ Different superscripts indicate differences $(P<0.05)$. NGH $=$ natural mountain grassland hay; $\mathrm{PAS}=$ pasture

bered (ON) FA and cis-9,cis-12,cis-15-18:3 from the milk fat content and yield, 16:1 and 16:0 percentages. Figure 2B shows the biplot resulting from principal component analysis applied to the different diets. The hay-based diets with RS and CS diets were located in one cluster at the center of the map. The PAS3 diet was opposed to the CONC diet according to PC1. The milk 18:0, cis-9-18:1, trans-11-18:1, and cis-9,trans-1118:2 percentages were closely associated with PAS3 diet, whereas short- and medium-chain (mostly satu- rated) FA were associated with the CONC diet. The milk cis-9,trans-13-18:2 and cis-9,cis-12-18:2 were associated with PAS6 and CS diets, respectively.

\section{Milk Lipolytic System}

During the preexperiment, the Tarentaise cows had significantly lower milk initial FFA and LPL activity than the Montbéliarde cows $(P<0.01$, Table 12). The difference between the 2 breeds in milk initial FFA and LPL activity was more important in Experiment 1 than in Experiment 2 (interaction breed $\times$ experiment; $P=$ $0.01)$.

During Experiment 1, postmilking lipolysis was lowest $(P<0.01)$ for the CONC and CS groups and highest for the RS group (Table 13). The Tarentaise cows had significantly lower milk initial FFA and LPL activity than the Montbéliarde cows. The Tarentaise also had lower lipolysis than Montbéliarde cows for the RS and NGH diets (interaction diet $\times$ breed, $P=0.02$ ). During Experiment 2, the Tarentaise cows had lower milk initial FFA than the Montbéliarde cows $(-27 \%, P=0.05$, Table 14). Milk LPL activity was positively and significantly correlated with lipolysis $(\mathrm{r}=+0.48 ; \mathrm{n}=72)$ when all data from Experiments 1 and 2 were pooled.

\section{DISCUSSION}

\section{Milk Yield and Composition}

The lower milk fat and protein yield and content with the RS diet are likely due to the lower DM and PDI intake because of feed refusals and a relatively low nutritive value of the grass silage studied in the present study. The high milk fat content of the CS group is consistent with the high total FA intake observed with this diet (Table 2) and the fact that diets rich in slowly degradable starch allow a higher acetate + butyrate:propionate ratio in the rumen (Chilliard et al., 2000). Surprisingly, the milk fat content was high for the CONC diet, in disagreement with studies in which high-grain and low-roughage diets were fed to cows (Bauman and Griinari, 2003; Loor et al., 2005a). This could be due in part to the fact that diet was given in limited amounts and thus to the lack of milk yield increase. Another reason for the lack of milk fat depression is the 4-times per day distribution of concentrate. Milk fat content was higher indeed with a continuous feeding regimen than with one distribution per day (Banks et al., 1980). Furthermore, the addition of a ruminal buffer $\left(\mathrm{CaCO}_{3}\right)$ prevented a subacidosis situation and thus contributed to maintain a high milk fat content.

During Experiment 2, after 6 wk, cows had lower milk yield than after $3 \mathrm{wk}$, and the decrease was more 
A)

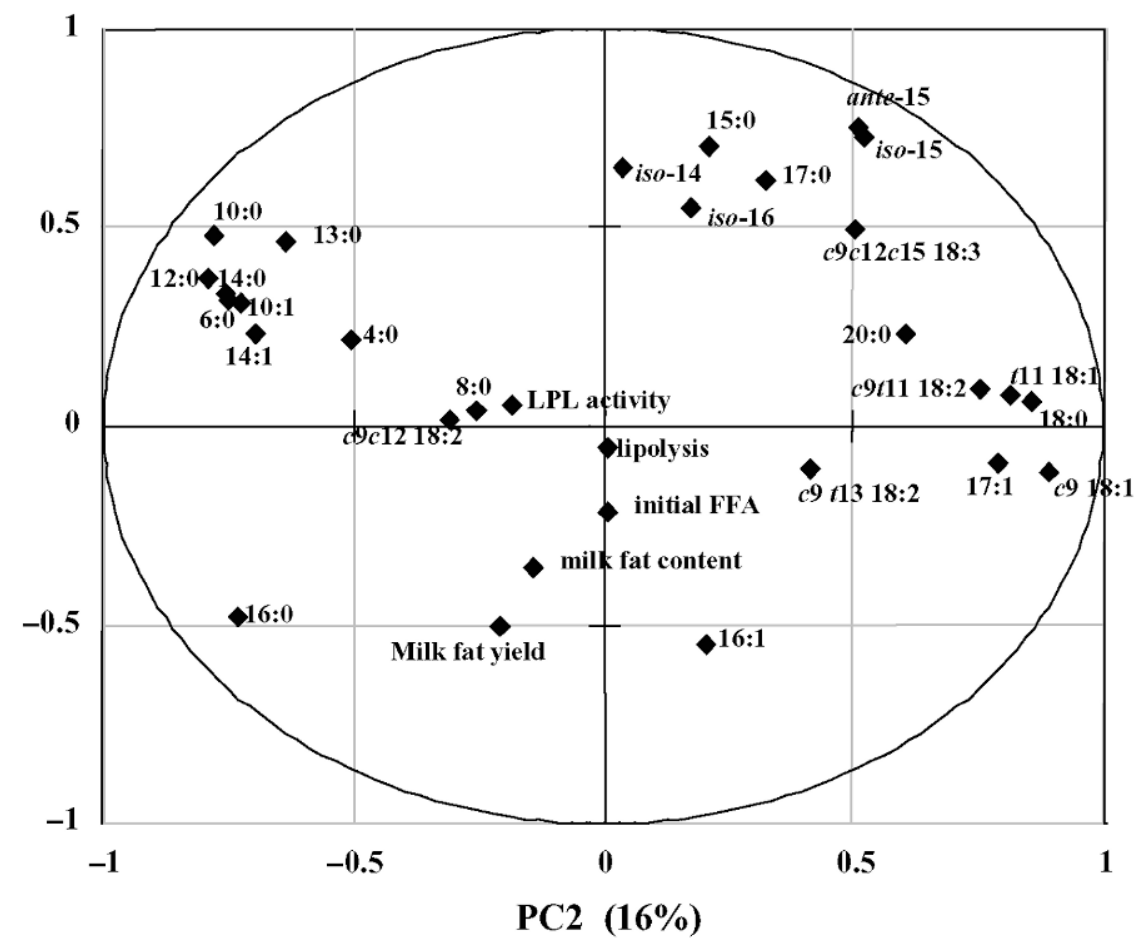

PC1 (31\%)

B)

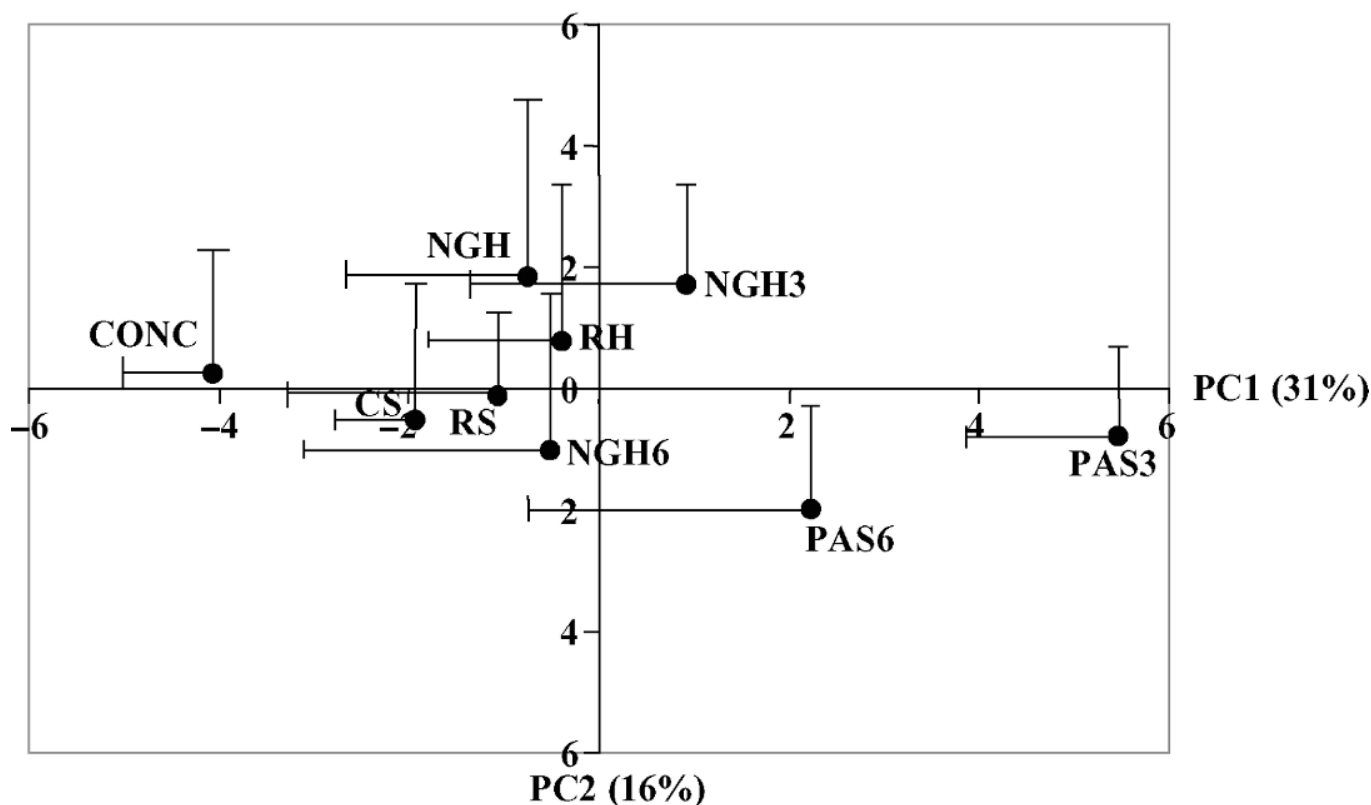

Figure 2. Principal component analysis (PCA) of the data obtained on 72 milks (5 diets with 8 cows, and 2 diets with 8 cows and 2 periods). A) Plot of variables projected on the first 2 principal components (PC1 and PC2) describing the relationships among milk fatty acids, fat content and yield, and lipolytic system. B) Plots on the first 2 PC showing the distribution of milk samples labeled as diets. Each point represents the barycentre, and the dispersion on each axis corresponds to the standard error for each diet. The PCA analyzes the relationships between data of high dimension (multivariate) by a graphical representation. The PCA involves a mathematical procedure that transforms a number of possibly correlated variables into a smaller number of uncorrelated variables called PC. The first PC accounts for as much of the variability in the data as possible, and each succeeding component accounts for as much of the remaining variability as possible. $\mathrm{CONC}=$ concentrate; $\mathrm{CS}=$ corn silage; $\mathrm{RS}=$ ryegrass silage; $\mathrm{RH}=$ ryegrass hay; NGH3 or NGH6 = mountain natural grassland hay fed at 3 or $6 \mathrm{wk}$, respectively; PAS3 or PAS6 = pasture at 3 or $6 \mathrm{wk}$, respectively; LPL = lipoprotein lipase. 
Table 12. Effect of cow breed on initial FFA content of milk, postmilking lipolysis, and milk lipoprotein lipase activity in preexperimental period

\begin{tabular}{|c|c|c|c|c|c|c|c|c|}
\hline \multirow[b]{3}{*}{ Item $^{1}$} & \multirow{2}{*}{\multicolumn{2}{|c|}{ Experiment 1}} & \multirow{2}{*}{\multicolumn{2}{|c|}{ Experiment 2}} & \multirow[b]{3}{*}{ SEM } & \multicolumn{3}{|c|}{$P$-value } \\
\hline & & & & & & & & Breed $x$ \\
\hline & Mo & $\mathrm{Ta}$ & $\overline{\mathrm{Mo}}$ & $\mathrm{Ta}$ & & Breed & Experiment & experiment \\
\hline Lipolysis $(\mu \mathrm{Eq} / 100 \mathrm{~g}$ of fat/24 h) & 588 & 133 & 114 & 69 & 50 & $<0.01$ & $<0.01$ & 0.01 \\
\hline Lipoprotein lipase activity $(\mathrm{nmol} / \mathrm{min}$ per $\mathrm{mL}$ ) & 760 & 649 & 626 & 597 & 56 & 0.43 & 0.29 & 0.64 \\
\hline
\end{tabular}

${ }^{1} \mathrm{Mo}=$ Montbéliarde cows; Ta $=$ Tarentaise cows (for each breed, $\mathrm{n}=20$ and 8 for Experiments 1 and 2, respectively). Lipolysis $=\mathrm{FFA}$ after $24 \mathrm{~h}$ of cold storage - initial FFA. Data were least squares means.

marked with the pasture diets. Because of the advanced grass phenological stage, the nutritive value of pasture at wk 6 may have been inadequate to cover energy and nitrogen requirements. The plasma NEFA and BHBA concentrations were higher, and the glycemia and plasma and milk urea were lower for the PAS6 group. This metabolic profile indicates that the cows grazing pasture at 6 wk were underfed (Chilliard et al., 1995), resulting in a significant decrease in milk protein content. The results observed with the PAS6 diet are in agreement with a previous study that compared low allowance to high allowance pasture (Bargo et al., 2002). As previously observed in many studies (INRA, 1989), milk Ca content did not vary according to the diet. Milk phosphorus content was higher in the CONC and CS groups because of the high $\mathrm{P}$ intake with these diets (INRA, 1989).

As reported in previous studies, Tarentaise cows had lower milk, fat, and protein yield (Coulon et al., 2001). In our experiment, the greater protein content of Tarentaise cows is explained both by a small proper effect of the breed (Coulon et al., 2001) and the numerically higher energy balance (Coulon and Rémond, 1991). The higher milk P content of Tarentaise cows was not described previously.

\section{Milk Fatty Acid Composition}

Our study highlights the strong difference between young pasture and high-concentrate diets for their milk
FA profile. The decrease in the proportion of mediumchain FA with 10 to 14 carbons with pasture is in agreement with Kelly et al. (1998). This decrease is probably due in part to the more important amount of dietary linoleic and linolenic acids provided by pasture than by the CONC diet (Tables 3 and 5). These polyunsaturated FA, their biohydrogenation products, or both are potent inhibitors of mammary synthesis of FA with 10 to 14 carbons through a direct inhibitory effect on acetyl-CoA carboxylase activity (Chilliard et al., 2000; Bauman and Griinari, 2003).

In contrast, the nature of forage had no effect on the proportion of butyric acid and short-chain FA with 6 or 8 carbon chain lengths. These FA are synthesized in part by metabolic pathways not involving malonyl-CoA and acetyl-CoA carboxylase (Chilliard et al., 2000), which should not be much influenced by the nature of forage. The lack of modification of milk percentage of short-chain FA suggests also that the availability of acetate and BHBA for the mammary gland was sufficient.

Differences in milk percentages of several $\mathrm{ON}$ and BC FA appeared between grass-based diets and CONC or CS diets (Figure 2). The higher content of ON and BC FA with grass-based diets is in agreement with the greater percentages of $\mathrm{ON}$ and $\mathrm{BC}$ FA in milk fat from cows fed low-concentrate vs. high-concentrate diets (Loor et al., 2005a) or goats fed alfalfa hay vs. corn silage (Chilliard et al., 2003). Microbial synthesis of these FA seems to be enhanced by diets rich in fiber

Table 13. Effect of cow breed and nature of forages on initial FFA content of milk, postmilking lipolysis, and milk lipoprotein lipase activity (Experiment 1)

\begin{tabular}{|c|c|c|c|c|c|c|c|c|c|c|c|}
\hline \multirow[b]{3}{*}{ Item $^{1}$} & \multirow{2}{*}{\multicolumn{5}{|c|}{ Diet }} & \multirow{2}{*}{\multicolumn{2}{|c|}{ Breed }} & \multirow[b]{3}{*}{ SEM } & \multicolumn{3}{|c|}{$P$-value } \\
\hline & & & & & & & & & \multirow[b]{2}{*}{ Diet } & \multirow[b]{2}{*}{ Breed } & \multirow{2}{*}{$\begin{array}{l}\text { Diet } \times \\
\text { breed }\end{array}$} \\
\hline & $\overline{\mathrm{CONC}}$ & $\mathrm{CS}$ & $\mathrm{RS}$ & $\mathrm{RH}$ & $\mathrm{NGH}$ & Mo & $\mathrm{Ta}$ & & & & \\
\hline Lipolysis $(\mu \mathrm{Eq} / 100 \mathrm{~g}$ of fat/24 h) & $123^{\mathrm{a}}$ & $66^{\mathrm{a}}$ & $289^{c}$ & $157^{\mathrm{ab}}$ & $248^{\mathrm{bc}}$ & 273 & 80 & 40 & $<0.01$ & $<0.01$ & 0.02 \\
\hline Lipoprotein lipase activity $(\mathrm{nmol} / \mathrm{min}$ per $\mathrm{mL})$ & 1,069 & 803 & 917 & 1,160 & 1,059 & 1,079 & 923 & 100 & 0.12 & 0.09 & 0.09 \\
\hline
\end{tabular}

${ }^{\mathrm{a}-\mathrm{c}}$ Different letters within row indicate statistically significant difference between the means $(P<0.05)$.

${ }^{1} \mathrm{Mo}=$ Montbéliarde cows; $\mathrm{Ta}=$ Tarentaise cows; $\mathrm{CONC}=$ concentrate $; \mathrm{CS}=$ corn silage RS = ryegrass silage $; \mathrm{RH}=\mathrm{ryegrass}$ hay; $\mathrm{NGH}=$ mountain natural grassland hay. Lipolysis = FFA after $24 \mathrm{~h}$ cold storage - initial FFA. Data are least squares means. 
Table 14. Effect of cow breed and nature of forages on initial FFA content of milk, postmilking lipolysis, and milk lipoprotein lipase activity (Experiment 2)

\begin{tabular}{|c|c|c|c|c|c|c|c|}
\hline \multirow[b]{2}{*}{ Item $^{1}$} & \multicolumn{2}{|c|}{ Diet } & \multicolumn{2}{|c|}{ Breed } & \multirow[b]{2}{*}{ SEM } & \multicolumn{2}{|c|}{$P$-value } \\
\hline & NGH6 & PAS6 & Mo & $\mathrm{Ta}$ & & Diet & Breed \\
\hline Initial FFA ( $\mu \mathrm{Eq} / 100 \mathrm{~g}$ of fat) & 205 & 196 & 232 & 170 & 21 & 0.74 & 0.05 \\
\hline Lipolysis $(\mu \mathrm{Eg} / 100 \mathrm{~g}$ of fat/24 h) & 61 & 148 & 143 & 65 & 34 & 0.10 & 0.13 \\
\hline Lipoprotein lipase activity $(\mathrm{nmol} / \mathrm{min}$ per $\mathrm{mL}$ ) & 511 & 563 & 645 & 429 & 96 & 0.72 & 0.14 \\
\hline
\end{tabular}

${ }^{1} \mathrm{Mo}=$ Montbéliarde cows; Ta = Tarentaise cows; NGH6 = mountain natural grassland hay fed at $6 \mathrm{wk}$; PAS6 = pasture at $6 \mathrm{wk}$. Lipolysis = FFA after $24 \mathrm{~h}$ cold storage - initial FFA. Data were least squares means.

because dietary fiber content was positively related to the percentage of ON and BC FA in ruminal bacteria (Sauvant and Bas, 2001).

The increase $(+7.3 \mathrm{~g} / 100 \mathrm{~g})$ in the milk content of $\mathrm{cis}$ 9-18:1 at pasture compared with diets from Experiment 1 (Tables 9 and 10) is typically observed in cows grazing pasture as opposed to cows fed winter diets (Timmen and Patton, 1988; Kelly et al., 1998). However, the high plasma NEFA and BHBA concentrations and the low glycemia suggest that cows grazing the PAS6 diet were partly underfed. Because lactating animals that consume less energy than required exhibit significant increase in milk 18:0 and cis-9-18:1 provided by tissuemobilized long-chain FA (Chilliard et al., 2003), this factor could have increased the effect of pasture per se.

Pasture feeding, when compared with the CONC and CS diets, increased trans-11-18:1 and cis-9,trans-1118:2 percentages, especially at the earlier growth stage (PAS3) of pasture (Figure 2). The higher 18:3 intake with young grass (Dewhurst et al., 2001; Loor et al., 2002; Table 2) and either its lower fiber content or effects of fresh grass components (e.g., sugars) could interact to enhance the ruminal formation of biohydrogenation intermediates of polyunsaturated FA as cis9,trans-11-18:2 and trans-11-18:1. The milk cis-9,trans11-18:2 content with the CONC diet was lower $(0.4 \%)$ than reported by Jiang et al. (1996; 0.7\%) or Loor et al. (2005a; $0.8 \%$ ) with a 35:65 forage-to-concentrate ratio. The difference could not be explained by the intake of the sum of 18-carbon FA (785, 314, and $251 \mathrm{~g} / \mathrm{d}$, for Jiang et al. (1996), Loor et al. (2005a), and our study, respectively). Furthermore, in the present study, the low milk trans-11-18:1 and cis-9,trans-11-18:2 percentages could result from a more complete ruminal biohydrogenation of dietary polyunsaturated FA related to the fact that the concentrate was offered 4 times daily. Thus the resulting lower ruminal yield of trans11-18:1 would result in a lower mammary synthesis of cis9,trans-11-18:2. The correlation across all diets between percentages of trans-11-18:1 and cis-9,trans-11-18:2 in milk fat was very high. This confirms that trans-11-18:1 is both a product (rumen) and a precursor (mammary gland) of cis-9,trans-11-18:2. We observed a similar slope $($ cis- 9 ,trans-11-18:2 $=0.44 \times$ trans $-11-18: 1+0.08$; $\mathrm{r}=0.96, \mathrm{n}=72, P<0.001)$ for the relationships between cis-9,trans-11-18:2 and trans-11-18:1 as Lawless et al. (1998) in cows (0.46) and Chilliard et al. (2003) in goats (0.40) fed various diets.

Minor differences between diets appeared on milk fat percentage of linoleic acid (1.0 to 1.8\%), which was lower than in most published studies on diets based on forages (usually between 2 and 3\%; Chilliard et al., 2001). Nevertheless, some authors observed lower values (from 0.8 to $1.2 \%$ ) with a grass silage-based diet (Precht and Molkentin, 1997; Offer, 2002). The milk linolenic acid percentage is in agreement with values observed with diets based on grass (around 1\%, Kelly et al., 1998; Lawless et al., 1998; Offer, 2002). Surprisingly, the highest values were not observed with pasture but with the hay diets, whereas the estimated linolenic acid intake with young pasture (PAS3) was higher than that with a hay diet. It is likely that the biohydrogenation of linolenic acid was more important with pasture than with hay-based diets, as observed by Doreau et al. (2003), and in agreement with the lower estimated transfer efficiency of linolenic acid from intake to milk with pasture diets.

To our knowledge, no previous study compared Montbéliarde and Tarentaise breeds. The breed differences in milk FA composition are generally minor (see below for references) when compared with the effects of dietary manipulation or variations among individual cows. Milk FA profile from Tarentaise cows presents, however, some interesting particularities because it has much lower palmitic acid percentage $(-3.4 \mathrm{~g} / 100 \mathrm{~g}$ of FA), and higher 18:0, cis-9,cis-12-18:2, and cis-9,cis12,cis-15-18:3 percentages than in Montbéliarde cows receiving the same diet. Furthermore, breed-diet interactions appeared in Experiment 2. Milk from Tarentaise cows was poorer in trans-11-18:1 and cis-9,trans11-18:2 than that from Montbéliarde when cows were fed pasture diets, but not when fed hay. Moreover, milk from Tarentaise cows was lower in 16:0 and richer in cis-9-18:1 and cis-9,cis-12,cis-15-18:3 percentages than 
that from Montbéliarde cows when animals were fed the NGH diet but not when fed pasture. An effect of cow breed on milk 16:0 percentage has been already reported. Milk 16:0 percentage ranked by breed was Tarentaise $<$ Montbéliarde (in the present study) $<$ Holstein $(+1.3 \mathrm{~g} / 100 \mathrm{~g}$ of FA compared with Montbéliarde; Lawless et al., 1999) < Jersey (+2.7 g/100 g compared with Holstein; Drackley et al., 2001). However, other studies did not report any difference between Holstein and Jersey breeds (Kelsey et al., 2003) or even lower percentage of 16:0 in milk fat from Jersey cows $(+2.2$ g/100 g; Beaulieu and Palmquist, 1995). Milk trans-1118:1 and cis-9,trans-11-18:2 percentages did not differ between our 2 breeds during preexperimental periods. Only small effects of cow breed on milk CLA content have been reported by Lawless et al. $(1999 ;+0.36 \mathrm{~g} / 100$ g of FA; Montbéliarde > Dutch Holstein/Friesian), by Kelsey et al. $(2003 ;+0.03$ g/100 g; Holstein > Brown Swiss), and by White et al. (2001; +0.10 g/100 g; Holstein $>$ Jersey).

\section{Milk Lipolytic System}

Postmilking lipolysis and LPL activity are positively correlated in the present study, contrary to results of Chazal and Chilliard (1986), who observed that milk LPL activity decreased when lipolysis increased in pregnant, late-lactation cows. In our study, the correlation could be due to the fact that animals were in mid lactation and effect of diet or individual cows became predominant.

The nature of forage modifies milk lipolysis. The higher milk lipolysis with the RS diet in the present study was previously noted by Chazal et al. (1987) and could be due to the lower milk yield observed with this diet because Chazal and Chilliard (1986) reported a negative correlation between milk lipolysis and milk yield. Seasonal variations in initial FFA were reported by Chazal and Chilliard (1986), who observed that the milk FFA content was low in winter and increased to a maximum in July.

Although Chazal and Chilliard (1987) did not observe any difference between Friesian and Montbéliarde cows during late lactation, the Tarentaise cows in the present study had lower milk initial FFA and postmilking lipolysis than Montbéliarde cows, which could represent a further positive particularity of the Tarentaise breed. Because feeding PUFA-rich diets to cows or goats decreased milk fat lipolysis, whereas 16:0 feeding increased it (Chilliard, 1982; Chilliard et al., 2003), it could be that the high content of PUFA and the low content of 16:0 in Tarentaise cow milk are linked to its lower level of postmilking lipolysis.

\section{CONCLUSIONS}

The present study shows that the nature of forage can induce large variations in the milk FA profile, notably in the cis-9,trans-11 isomer of CLA and trans-11-18:1 percentages. When compared with concentrate diet, pasture, especially at earlier growth, decreased milk FA with a putative negative effect (12:0 to 16:0) and increased those having a potential interest for human health (trans-11,cis-9-18:2 and cis-9,cis-12,cis-15-18:3), respectively. Some differences, albeit small, were observed on milk FA composition according to grass preservation mode. Milk of Tarentaise cows presents interesting particularities, with a much lower palmitic acid percentage and higher stearic acid and polyunsaturated FA in milk fat, and lower postmilking lipolysis than Montbéliarde cows. Furthermore responses of milk cis9-18:1 and cis-9,cis-12,cis-15-18:3 differ between the 2 breeds and could enhance the advantages of Tarentaise cows when they are fed hay diets. Modifying the nature of forage can allow rapid and significant changes in cow milk FA composition and lipolytic system. The potential effects of these changes on other aspects of the nutritional and sensorial quality of dairy products need further investigation.

\section{ACKNOWLEDGMENTS}

The authors acknowledge the assistance of F. Monsallier, E. Albaret, and the team of Domaine de la Borie, INRA Marcenat for feeding, milking, blood sampling, and care for cows, as well as P. Capitan, M. Tourret, C. Delavaud, and J. Fléchet for help in laboratory analyses. This research was supported in part by AQS-F15/ 00 P 0174 program (2000).

\section{REFERENCES}

AFNOR. 1992. Lait. Détermination de la teneur en phosphore total du lait. Méthode par spectrométrie d'absorption moléculaire, Norme NF ISO 9874.

Association of Official Analytical Chemists. 1997. Official Methods of Analysis. 16th ed. AOAC Int., Gaithersburg, MD.

Banks, W., J. L. Clapperton, M. E. Kelly, A. G. Wilson, and R. J. M. Crawford. 1980. The yield, fatty acid composition and physical properties of milk fat obtained by feeding soya oil to dairy cows. J. Sci. Food Agric. 31:368-374.

Bargo, F., L. D. Muller, J. E. Delahoy, and T. W. Cassidy. 2002. Milk response to concentrate supplementation of high producing dairy cows grazing at two pasture allowances. J. Dairy Sci. 85:17771792 .

Bauman, D. E., and J. M. Griinari. 2003. Nutritional regulation of milk fat synthesis. Annu. Rev. Nutr. 2003:203-227.

Beaulieu, A. D., and D. L. Palmquist. 1995. Differential effects of high fat diets on fatty acid composition in milk of Jersey and Holstein cows. J. Dairy Sci. 78:1336-1344.

Chazal, M. P., and Y. Chilliard. 1986. Effect of stage of lactation, stage of pregnancy, milk yield and herd management on seasonal variation in spontaneous lipolysis in bovine milk. J. Dairy Res. 53:529-538. 
Chazal, M. P., and Y. Chilliard. 1987. Effect of breed of cow (Friesian and Montbéliarde) on spontaneous and induced lipolysis in milk. J. Dairy Res. 54:7-11.

Chazal, M. P., Y. Chilliard, and J. B. Coulon. 1987. Effect of nature of forage on spontaneous lipolysis in milk from cows in late lactation. J. Dairy Res. 54:13-18.

Chilliard, Y. 1982. Variations physiologiques des activités lipasiques et de la lipolyse spontanée dans les laits de vache, de chèvre et de femme: Revue bibliographique. Lait 62:126-154.

Chilliard, Y., M. Doreau, F. Bocquier, and G. E. Lobley. 1995. Digestive and metabolic adaptations of ruminants to variations in food supply. Pages 329-360 in Recent Dev. Nutr. Herbivores, Proc. IVth Int. Symp. Nutr. Herbivores. M. Journet, E. Grenet, M. H. Farce, M. Thériez, C. Demarquilly. INRA Editions, Paris, France.

Chilliard, Y., A. Ferlay, and M. Doreau. 2001. Effect of different types of forages, animal fat or marine oils in cow's diet on milk fat secretion and composition, especially conjugated linoleic acid (CLA) and polyunsaturated fatty acids. Livest. Prod. Sci. 70:31-48.

Chilliard, Y., A. Ferlay, R. Mansbridge, and M. Doreau. 2000. Ruminant milk fat plasticity: Nutritional control of saturated, polyunsaturated, trans and conjugated fatty acids. Ann. Zootech. 49:181-205.

Chilliard, Y., A. Ferlay, J. Rouel, and G. Lamberet. 2003. A review of nutritional and physiological factors affecting goat milk lipid synthesis and lipolysis. J. Dairy Sci. 86:1751-1770.

Coulon, J. B., P. D’Hour, J. P. Garel, and M. Petit. 1994. Level and pattern of winter concentrate allocation in dairy cows: Results in first lactation cows. Anim. Prod. 59:11-20.

Coulon, J. B., D. Dupont, S. Pochet, P. Pradel, and H. Duployer. 2001. Effect of genetic potential and level of feeding on milk protein composition. J. Dairy Res. 68:569-577.

Coulon, J. B., and B. Rémond. 1991. Variations in milk output and milk protein content in response to the level of energy supply to the dairy cow: A review. Livest. Prod. Sci. 1:31-47.

Dewhurst, R. J., N. D. Scollan, S. J. Youell, J. K. S. Tweed, and M. O. Humphreys. 2001. Influence of species, cutting date and cutting interval on the fatty acid composition of grasses. Grass Forage Sci., 56:68-74.

Doreau, M., K. Ueda, and C. Poncet. 2003. Fatty acid ruminal metabolism and intestinal digestibility in sheep fed ryegrass silage and hay. Trop. Subtropical Agroecosys. 3:289-293.

Drackley, J. K., A. D. Beaulieu, and J. P. Elliott. 2001. Responses of milk fat composition to dietary fat or nonstructural carbohydrates in Holstein and Jersey Cows. J. Dairy Sci. 84:1231-1237.

Faulconnier, Y., M. Thévenet, J. Fléchet, and Y. Chilliard. 1994. Lipoprotein lipase and metabolic activities in incubated bovine adipose tissue explants: Effects of insulin, dexamethasone, and fetal bovine serum. J. Anim. Sci. 72:184-191.

Ferlay, A., and Y. Chilliard. 1999. Effects of the infusion of nonselective beta-, and selective beta1- or beta2-adrenergic agonists, on body fat mobilisation in underfed or overfed non-pregnant heifers. Reprod. Nutr. Dev. 39:409-421.

Folch, J., M. Lees, and G. H. Sloane Stanley. 1957. A simple method for the isolation and purification of total lipids from animal tissues. J. Biol. Chem. 226:497-509.

Glass, R. L. 1971. Alcoholysis, saponification and the preparation of fatty acid methyl esters. Lipids 6:919-925.

Griinari, J. M., B. A. Corl, S. H. Lacy, P. Y. Chouinard, K. V. V. Nurmela, and D. E. Bauman. 2000. Conjugated linoleic acid is synthesized endogenously in lactating dairy cows by $\Delta^{9}$-desaturase. J. Nutr. 130:2285-2291.

Institut National de la Recherche Agronomique (INRA). 1989. Ruminant Nutrition. Recommended allowances and feed tables. R. Jarrige, éd. John Libbey Eurotext, London, UK.

Jellema, A. 1991. Determination of free fatty acids in milk and milk products. Bull. Int. Dairy Fed., no. 265.Int. Dairy Fed., Brussels, Belgium.
Jiang, J., L. Bjoerck, R. Fondén, and M. Emanuelson. 1996. Occurrence of conjugated cis-9, trans-11-octadecadienoic acid in bovine milk: Effect of feed and dietary regimen. J. Dairy Sci. 79:438-445.

Kay, J. K., T. R. Mackle, M. J. Auldist, N. A. Thomson, and D. E. Bauman. 2004. Endogenous synthesis of cis-9, trans-11 conjugated linoleic acid in dairy cows fed fresh pasture. J. Dairy Sci. 87:369-378.

Kelly, M. L., E. S. Kolver, D. E. Bauman, M. E. Van Amburgh, and L. D. Muller. 1998. Effect of intake of pasture on concentrations of conjugated linoleic acid in milk of lactating cows. J. Dairy Sci. 81:1630-1636.

Kelsey, J. A., B. A. Corl, R. J. Collier, and D. E. Bauman. 2003. The effect of breed, parity, and stage of lactation on conjugated linoleic acid (CLA) in milk fat from dairy cows. J. Dairy Sci. 86:2588-2597.

Lawless, F., J. J. Murphy, D. Harrington, R. Devery, and C. Stanton. 1998. Elevation of conjugated cis-9, trans-11-octadecadienoic acid in bovine milk because of dietary supplementation. J. Dairy Sci. 81:3259-3267.

Lawless, F., C. Stanton, P. L'Escop, R. Devery, P. Dillon, and J. J. Murphy. 1999. Influence of breed on bovine milk cis-9, trans-11conjugated linoleic acid content. Livest. Prod. Sci. 62:43-49.

Loor, J. J., A. Ferlay, A. Ollier, M. Doreau, and Y. Chilliard. 2005a. Relationship among trans conjugated fatty acids and bovine milk fat yield due to dietary concentrate and linseed oil. J. Dairy Sci. 88:726-740.

Loor, J. J., A. Ferlay, A. Ollier, K. Ueda, M. Doreau, and Y. Chilliard. 2005b. High-concentrate diets and polyunsaturated oils alter trans and conjugated isomers in bovine rumen, blood, and milk. J. Dairy Sci. 88:3986-3999.

Loor, J. J., J. H. Herbein, and C. E. Polan. 2002. Trans18:1 and 18:2 isomers in blood plasma and milk fat of grazing cows fed a grain supplement containing solvent-extracted or mechanically extracted soybean meal. J. Dairy Sci. 85:1197-1207.

Offer, N. W. 2002. Effects of cutting and ensiling grass on levels of CLA in bovine milk. Pages 16-17 in the XIIIth Int. Silage Conf. Scotland. L. M. Gechie and C. Thomas, ed. Auchincruive, UK.

Palmquist, D. L., A. D. Beaulieu, and D. M. Barbano. 1993. Feed and animal factors influencing milk fat composition. J. Dairy Sci. 76:1753-1771.

Parodi, P. W. 1999. Conjugated linoleic acid and other anticarcinogenic agents of bovine milk fat. J. Dairy Sci. 82:1339-1349.

Pearce, K. N. 1977. The complexometric determination of calcium in dairy products. N. Z. J. Dairy Sci. Technol. 12:113-115.

Potts, T. J. 1967. Colorimetric determination of urea in feeds (Report of AOAC Committee). J. AOAC Int. 50:56-58.

Precht, D., and J. Molkentin. 1997. Effect of feeding on conjugated cis-9, trans-11 octadecadienoic acid and other isomers of linoleic acid in bovine milk fats. Nahrung 41:330-335.

SAS Institute. 2000. SAS User's guide: Statistics. Version 8 ed. SAS Inst. Inc., Cary, NC.

Sauvant, D., and P. Bas. 2001. La digestion des lipides chez les ruminants. INRA Prod. Anim. 14:303-310.

Sébédio, J. L., C. Alasnier, S. Grégoire, and L. Leclère. 1999. Méthylation des lipides contenant des acides gras conjugués (CLA). Méthodes de Laboratoire, M/LAB/012/0, INRA, Paris, France.

Timmen, H., and S. Patton. 1988. Milk fat globules: Fatty acid composition, size and in vivo regulation of fat liquidity. Lipids 23:685-689.

Ulberth, F., and M. Henninger. 1994. Quantitation of trans fatty acids in milk fat using spectroscopic and chromatographic methods. J. Dairy Res. 61:517-527.

Ulbricht, T. L. V., and D. A. T. Southgate. 1991. Coronary heart disease: Seven dietary factors. Lancet 338:985-992.

Vessier, I. 1999. Expérimentation animale: Biologie, éthique, réglementation. INRA Prod. Anim. 12:365-375.

White, S. L., J. A. Bertrand, M. R. Wade, S. P. Washburn, J. T. Jr. Green, and T. C. Jenkins. 2001. Comparison of fatty acid content of milk from Jersey and Holstein Cows consuming pasture or a total mixed ration. J. Dairy Sci. 84:2295-2301. 